\title{
Exacerbations in adults with asthma: A systematic review and external validation of prediction models
}

Rik JB Loymans, $\mathrm{MD}^{1^{*}}$ Thomas PA Debray, PhD ${ }^{2,3}$ Persijn J Honkoop, PhD ${ }^{4}$ Evelien H Termeer, MD ${ }^{5}$ Jiska B Snoeck-Stroband, $\mathrm{PhD}^{4}$ Tjard RJ Schermer, $\mathrm{PhD}^{5}$ Willem JJ Assendelft, $\mathrm{PhD}^{5}$ Merel Timp, $\mathrm{MSc}^{1}$ Kian Fan Chung, $\mathrm{PhD}^{6}$ Ana R Sousa, $\mathrm{PhD}^{7}$ Jaap K Sont, $\mathrm{PhD}^{4}$ Peter J Sterk, $\mathrm{PhD}^{8}$ Helen K Reddel, $\mathrm{PhD}^{9}$ Gerben ter Riet $\mathrm{PhD}^{1}$

* corresponding author: AMC-UvA, room J2-218, P.O. Box 22660, 1100 DD Amsterdam, the Netherlands. T: +31(0)20 5666774 E: r.j.loijmans@amc.nl

1 Department of General Practice, Academic Medical Center, P.O. Box 22660, 1100 DD Amsterdam, the Netherlands 2 Julius Center for Health Sciences and Primary Care, University Medical Center, P.O. Box 85060, 3508 AB Utrecht, the Netherlands 3 Cochrane Netherlands, University Medical Center Utrecht, P.O. Box 85500, 3508 GA Utrecht, the Netherlands 4 Department of Medical Decision Making, Leiden University Medical Center, P.O. Box 9600, 2300 RC Leiden, the Netherlands 5 Department of Primary and Community Care, Radboud University Nijmegen Medical Centre, P.O. Box 9101, 6500 HB Nijmegen, the Netherlands 6 Experimental Airway Disease, National Heart and Lung Institute, Imperial College, London \& Royal Brompton NIHR Biomedical Research Unit, Sydney Street, London SW3 6NP 2AZ, United Kingdom 7 Respiratory Therapeutic Unit, GlaxoSmithKline, Stockley Park, Uxbridge UB11 1BT, United Kingdom 8 Department of Respiratory Medicine, Academic Medical Center, P.O. Box 22660, 1100 DD Amsterdam, the Netherlands 9 Clinical Management Group, Woolcock Institute of Medical Research - University of Sydney, 431 Glebe Point Road, Glebe NSW 2037 Sydney, Australia

T. Schermer reports grants from The Netherlands Organisation for Health Research and Development, grants from Dutch Lung Foundation, during the conduct of the study; KF. Chung reports personal fees from GSK, AZ, Teva, Boehringer Ingelheim, Novartis and J\&J, grants from Pfizer, GSK and Merck, outside the submitted work; A. Sousa is an employee and holds stock in GlaxoSmithKline; P. Sterk reports grants from the Innovative Medicines Initiative covered by the European Union and the European Federation of Pharmaceutical Industries and Associations, outside the submitted work; H. Reddel is Chair of the GINA Science Committee. All other authors have nothing to disclose. 


\section{ABSTRACT}

Background: Several prediction models assessing future risk of exacerbations in adult patients with asthma have been published. Applicability of these models is uncertain because their predictive performance has often not been assessed beyond the population in which the ones they were derived.

Objective: This study aimed to identify and critically appraise prediction models for asthma exacerbations and validate them in two clinically distinct populations.

Methods: PubMed and EMBASE were searched to April 2017 for reports describing adult asthma populations in which multivariable models were constructed to predict exacerbations during any time frame. After critical appraisal, the models predictive performances were assessed in a primary and a secondary care population for: author-defined exacerbations and for ATS/ERS-defined severe exacerbations.

Results: We found 12 reports from which 24 prediction models were evaluated. Three predictors (previous healthcare-utilisation, symptoms, and spirometry values) were retained in most models. Assessment was hampered by sub-optimal methodology and reporting, and by differences in exacerbation outcomes. Discrimination (AUROC) of models for author-defined exacerbations was better in the primary care population (mean 0.71 ) than in the secondary care population (mean 0.60 ); and similar ( 0.65 and 0.62 respectively) for ATS/ERS defined severe exacerbations. Model calibration was generally poor, but consistent between the two populations.

Conclusion: The preservation of three predictors in models derived from variable populations and the fairly consistent predictive properties of most models in two distinct validation populations suggest the feasibility of a generalizable model predicting severe exacerbations. Nevertheless, improvement of the models is warranted as predictive performances are below the desired level. 


\section{Key words}

adults, asthma, exacerbation, prediction model, primary care, secondary care, risk, validation

\section{Abbreviations}

$\begin{array}{ll}\text { ACCURATE } & \text { Asthma Control Cost-Utility RAndomized Trial Evaluation } \\ \text { ACQ } & \text { asthma control questionnaire } \\ \text { ACT } & \text { asthma control test } \\ \text { ATS/ERS } & \text { American Thoracic Society/European Respiratory Society } \\ \text { AUROC } & \text { area under the Receiver Operating Characteristic Curve (c-statistic) } \\ \text { CHARMS } & \text { CHecklist for critical Appraisal and data extraction for systematic Reviews of } \\ & \text { prediction Modelling Studies } \\ \text { COPD } & \text { chronic obstructive pulmonary disease } \\ \text { FeNO } & \text { fractional exhaled nitric oxide } \\ \text { FEV1 } & \text { forced expiratory volume in one second } \\ \text { TENOR } & \text { The Epidemiology and Natural History of Asthma: Outcomes and Treatment } \\ & \text { Regimens } \\ \text { U-BIOPRED } & \text { Unbiased BIOmarkers in PREDiction of respiratory disease outcomes }\end{array}$

\section{Highlight Box}

What is already known about this topic?

At least a dozen prediction models assessing future risk of exacerbations in adult patients with asthma have been reported. External validation of these models is scarce; added value for clinical practice therefore remains unclear.

What does this article add to our knowledge?

Identified prediction models, derived from diverse populations, demonstrated limited predictive capacities in two clinically distinct populations. Previous healthcare-utilisation, symptoms, and spirometry values proved strongly preserved predictors. Additional (bio)markers are needed to improve predictive capacities.

How does this study impact current management guidelines?

Performance of current prediction models for exacerbations asthma is not sufficient enough to assist practitioners in clinical practice in assessing future risk for exacerbations. 


\section{Introduction}

The starting point for treating patients with asthma is establishing their level of asthma control, ${ }^{1}$ which is defined by "the extent to which the manifestations of asthma have been reduced or removed by treatment". ${ }^{2}$ The concept of asthma control consists of two components. The first component is current control of symptoms, which can be established by several widely used and validated symptom scores, for example the Asthma Control Questionnaire $(A C Q),{ }^{3}$ or the Asthma Control Test (ACT). ${ }^{4}$ The second component is future risk of adverse outcomes such as exacerbations, fixed airflow limitation and medication side effects, of which exacerbations are the most important.

Generally accepted clinical instruments to assess exacerbation risk are lacking. Low lung function is commonly associated with greater risk of exacerbations ${ }^{5,6}$ although there are no standardised ways to convert actual lung function values into estimated risks. Besides poor lung function, several other risk factors for exacerbations have been identified, such as a history of one or more exacerbations in the previous year, poor medication adherence, incorrect inhaler technique, smoking, and blood eosinophilia. ${ }^{1}$ Assessing separate risk factors, however, does not provide a risk estimate of future adverse events for individual patients.

Prediction models that statistically integrate several risk factors enable practitioners to estimate risks for future outcomes, such as exacerbations. Previously published models

predicting exacerbations of asthma include the Profile of Asthma Risk, ${ }^{6}$ the Risk Score for Exacerbations, ${ }^{7}$ and the TENOR Risk Score. ${ }^{8}$ These models are generally easy to apply, and allow estimation of exacerbation risk at the level of the individual patient. Unfortunately, the applicability of the above-mentioned models remains preliminary: the validity of most models has only been assessed using data from the original development population. 
Moreover, some models have been derived in populations with specific entry criteria, for example by high asthma severity, ${ }^{8}$ or a mandatory history of a recent exacerbation. ${ }^{7}$ Consequently, at present, it remains unclear whether previously developed prediction models are able to accurately assess future risk of exacerbations for individuals in populations other than the one from which the model was derived. Therefore, we aimed to systematically identify all relevant prognostic prediction models for asthma exacerbations in adults, to critically appraise their quality, and to compare their predictive properties using data from two independent patient populations.

\section{Material and methods}

\section{Search strategy and selection criteria}

For this systematic review and external validation study, we included studies reported on (1) an adult (mean age greater than 18 years and no patients under 12) asthma population, describing the (2) development of prognostic multivariable (i.e. combining at least two factors) models, ${ }^{9}$ estimating individual probabilities for (3) asthma exacerbations by any definition during (4) any time frame aimed to (5) identify patients at increased risk for future adverse asthma outcomes in a clinical setting.

Predictor-finding studies that adjusted for covariates, and studies merely reporting on relative measures (odds ratios) rather than absolute risks were not included because they did not allowing estimation of individual patient risk. Studies reporting on single predictors were also excluded, except when these single predictors consisted of a composite score, as these may have better predictive capacities than single predictors. ${ }^{10}$ Finally, cross-sectional studies were excluded, as well as other non-longitudinal studies (e.g. predicting admission to 
hospital after emergency department visit) as this review aimed to identify models that predict future exacerbations.

EMBASE and PubMed databases were searched from their inception to April 1 2017, using a search strategy for prediction models from Ingui, ${ }^{11,12}$ modified to identify asthma exacerbations (appendix I). Reference lists of included studies and two review articles ${ }^{10,13}$ were also screened. Two researchers ( $R L$ and $M T)$ independently screened titles and then abstracts; all articles selected by at least one of the researchers were assessed in full text against the selection criteria. Relevant data were extracted by RL and checked by MT. Risk of bias assessment was performed according to the CHecklist for critical Appraisal and data extraction for systematic Reviews of prediction Modelling Studies (CHARMS) recommendations ${ }^{14}$ by $\mathrm{RL}$ and checked by $\mathrm{MT}$; inconsistencies were resolved by discussion.

\section{Data analysis}

Validation was performed for exacerbations as defined by the original authors of the model, as well as for severe exacerbations defined according to the American Thoracic Society/European Respiratory Society (ATS/ERS) task force (the use of systemic corticosteroids or an increase from a stable maintenance dose, for at least 3 days and/or a hospitalization or ER visit because of asthma, requiring systemic corticosteroids) ${ }^{15}$ in two separate validation populations.

Validation cohorts

Primary care cohort. The ACCURATE (Asthma Control Cost-Utility RAndomized Trial Evaluation) cohort consisted of 611 participants from a one-year pragmatic trial conducted in 131 general practices in the Netherlands between September 2009 and January 2012. This trial compared three treatment strategies targeted at achieving different levels of asthma control in patients with a physician's diagnosis of asthma, with at least one prescription of 
inhaled corticosteroids (ICS) in the previous year. ${ }^{16}$ During 1-year follow-up, $13 \%$ experienced at least one severe exacerbation.

Secondary care cohort. The U-BIOPRED (Unbiased BIOmarkers in PREDiction of respiratory disease outcomes) cohort comprised 317 adult asthma patients recruited from 16 clinical centres in 11 European countries. Participants were followed for an average of one year between 2010 and 2014. ${ }^{17}$ This cohort consisted of (A) non-smoking and (B) smoking or exsmoking ( $>=5$ pack years) patients with severe (uncontrolled symptoms despite high ICS doses) asthma. About 55\% of this cohort experienced one or more exacerbations during 12 month follow-up. In accordance with the real life situation, both cohorts contained smokers. More details are given in a previous report ${ }^{18}$ and Table E1.

\section{Statistical analysis}

Missing values in both validation sets were imputed using multiple imputation by chained equations, generating 10 datasets for each population. The amount of missing data was low in both validation cohorts: $2.3 \%$ in the ACCURATE population and $4.1 \%$ in the U-BIOPRED population. To evaluate the predictive performance of the retrieved prediction models, predictors were matched with corresponding variables in the validation datasets. Variables included in a model but missing from the validation datasets were replaced by a comparable proxy variable where available. When data for more than one predictor or a proxy were not available in both of the validation cohorts, that prediction model was excluded from further evaluation. ${ }^{19}$

For each model, the predicted risk of experiencing one or more asthma exacerbations (as defined by the model authors and as ATS/ERS-defined severe exacerbations) was calculated for each individual in the two validation datasets (table 1), using the published regression coefficients and intercept, or the risk scoring system published with the model. For 
validation of each model, a prediction horizon of 6 or 12 months was used, based on whichever of these was closer to the prediction horizon used in the development of that model.

Model performance assessment was conducted by calculating the area under the ROC curve (discrimination), the calibration slope, and the 'calibration-in-the-large'. ${ }^{20,21}$ The calibration slope indicates whether model predictions are too extreme (slope $<1$ ) or do not vary sufficiently across individuals (slope $>1$ ). The 'calibration-in-the-large' (citl) indicates whether, on average, the model over-predicts $(c i t \mid<0)$ or under-predicts (cit $>0)$ the outcome of interest We also generated calibration plots to visually assess the extent to which predicted risks were in agreement with observed outcomes across different ranges of predicted risk. All statistical analyses were conducted using STATA version 13.1 and $\mathrm{R}$ version 3.3.1. This study was registered in the PROSPERO database as CRD42016032689 (www.crd.york.ac.uk/Prospero/).

\section{RESULTS}

The literature search yielded 3,103 records of which 68 reports were assessed in full text (figure 1). The agreement between the two reviewers was 93.9\%; Cohen's kappa was moderate (0.58). The most common reason for exclusion was that the models were corrected for one or more covariates (assessing causality rather than prediction), and/or did not allow estimation of individual risk $(n=43)$. The Severity of Asthma score was not developed as a prediction model, ${ }^{22}$ however, an external validation study of the score generating five prediction models for different outcomes was included. ${ }^{23}$ Ultimately, 12 reports ${ }^{6-8,18,23-30}$ describing a total of 24 prediction models fulfilled the inclusion criteria (table 1; detailed summary of included models in Table E2). For external validation, one 
model was excluded as it contained multiple $(>10)$ variables that were absent in both validation sets; ${ }^{29}$ in another model, exacerbations were defined as unspecified serious adverse events, ${ }^{23}$ also hampering external validation. Hence, 22 models from 11 reports ${ }^{6-}$ ${ }_{8,18,23-28,30}$ were validated in the external datasets.

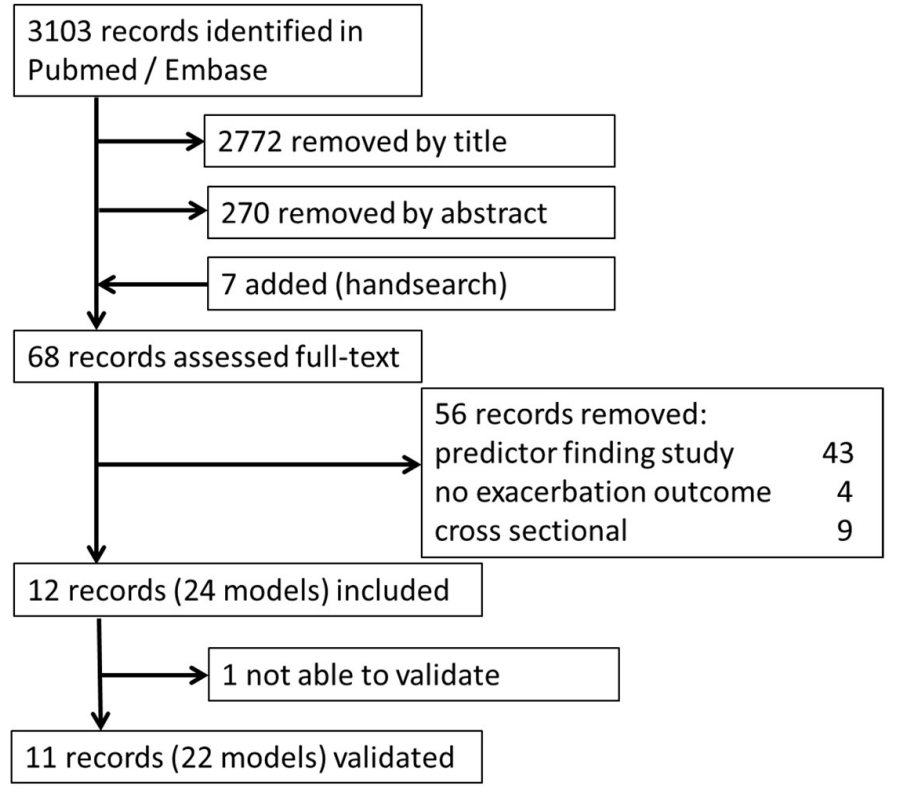

Figure 1: overview of systematic literature search

Table 1: overview of identified prediction reports $(n=12)$ and models $(n=24)$ * 


\begin{tabular}{|c|c|c|c|c|c|c|c|}
\hline $\begin{array}{l}1^{\text {st }} \text { author / } \\
\text { year } \\
\text { [reference] }\end{array}$ & $\begin{array}{l}\text { Number } \\
\text { of } \\
\text { models } \\
\text { reported }\end{array}$ & Population & $\begin{array}{l}\text { Events / } \\
\text { population } \\
\text { size (\%) }\end{array}$ & $\begin{array}{l}\text { Author } \\
\text { defined } \\
\text { outcome }\end{array}$ & $\begin{array}{l}\text { Prediction } \\
\text { horizon } \\
\text { (months) }\end{array}$ & $\begin{array}{l}\text { Modelling } \\
\text { technique }\end{array}$ & $\begin{array}{l}\text { Number of } \\
\text { predictors for } \\
\text { each reported } \\
\text { model }\end{array}$ \\
\hline $\begin{array}{l}\text { Loymans et } \\
\text { al } 2016[18]\end{array}$ & 3 & Primary care $\mathrm{RCT}$ & $\begin{array}{l}80 / 611 \\
(13)\end{array}$ & ATS/ERS & 12 & Logistic & $5 / 6 / 7$ \\
\hline $\begin{array}{l}\text { Bateman et } \\
\text { al } 2014 \text { [7] }\end{array}$ & 1 & 3 secondary care RCTs & $\begin{array}{l}1197 / 7446 \\
(16.1)\end{array}$ & ATS/ERS & 6 & Cox & 5 \\
\hline $\begin{array}{l}\text { Eisner et al } \\
2012[23]\end{array}$ & 5 & Mixed care cohort & N.R./2878 & $\begin{array}{l}\text { OCS, ED, SAE, } \\
\text { HOS, UV }\end{array}$ & 12 & $\begin{array}{l}\text { Logistic + } \\
\text { CART }\end{array}$ & $2 / 3 / 2 / 1 / 2$ \\
\hline $\begin{array}{l}\text { Sato et al } \\
2009[24]\end{array}$ & 1 & Secondary care cohort & $\begin{array}{l}16 / 78 \\
(21.3)\end{array}$ & $\begin{array}{l}\text { PEF decline/ } \\
\text { OCS/ED/HOS }\end{array}$ & 12 & CART & 3 \\
\hline $\begin{array}{l}\text { Osborne et } \\
\text { al } 2007[6]\end{array}$ & 3 & $\begin{array}{l}\text { Mixed care } \\
\text { administrative database }\end{array}$ & $\begin{array}{l}173 / 554 \\
(31.2)\end{array}$ & $\mathrm{ED} / \mathrm{UV} / \mathrm{HOS}$ & 30 & Poisson & $12 / 11 / 10$ \\
\hline $\begin{array}{l}\text { Miller et al } \\
2006[8]\end{array}$ & 3 & $\begin{array}{l}\text { Secondary care cohort } \\
\text { study }\end{array}$ & $\begin{array}{l}239 / 2821 \\
(8.5)\end{array}$ & ED/HOS & 6 & Logistic & $12 / 14 / 16$ \\
\hline $\begin{array}{l}\text { Peters et al } \\
2006[25]\end{array}$ & 2 & $\begin{array}{l}\text { Mixed care } \\
\text { administrative database }\end{array}$ & $\begin{array}{l}480 / 4788 \\
(10.0)\end{array}$ & ED/UV/HOS & 12 & CART & $2 / 4$ \\
\hline $\begin{array}{l}\text { Yurk et al } \\
2004[30]\end{array}$ & 1 & $\begin{array}{l}\text { Mixed care } \\
\text { administrative database }\end{array}$ & $N R / 4888$ & $\begin{array}{l}\mathrm{ED} / \mathrm{HOS} / \text { lost } \\
\text { activity days }\end{array}$ & 12 & Logistic & 14 \\
\hline $\begin{array}{l}\text { Schatz et al } \\
2003[26]\end{array}$ & 1 & $\begin{array}{l}\text { Mixed care } \\
\text { administrative database }\end{array}$ & $\begin{array}{l}83 / 6904 \\
(1.2)\end{array}$ & HOS & 12 & Logistic & 3 \\
\hline $\begin{array}{l}\text { Lieu et al } \\
1999[27]\end{array}$ & 2 & $\begin{array}{l}\text { Mixed care } \\
\text { administrative database }\end{array}$ & $\begin{array}{l}493 / 7141 \\
(6.9)\end{array}$ & ED/HOS & 12 & CART & $3 / 4$ \\
\hline $\begin{array}{l}\text { Ellman et al } \\
1997[28]\end{array}$ & 1 & Mixed care RCT & $\begin{array}{l}38 / 70 \\
(54.3)\end{array}$ & $\begin{array}{l}\text { FEV1 decline/ } \\
\text { SCS }\end{array}$ & 4.6 & $\begin{array}{l}\text { Repeated } \\
\text { cross } \\
\text { stratifications } \\
+ \text { Logistic }\end{array}$ & 3 \\
\hline $\begin{array}{l}\text { Grana et al } \\
1997[29]\end{array}$ & 1 & $\begin{array}{l}\text { Mixed care } \\
\text { administrative database }\end{array}$ & $\begin{array}{l}1000 / 54573 \\
(1.8)\end{array}$ & $\mathrm{HOS}$ & 12 & Logistic & 34 \\
\hline \multicolumn{8}{|c|}{$\begin{array}{l}\text { ATS/ERS severe exacerbations defined according to American Thoracic Society/European Respiratory Society criteria: }{ }^{15} \text { systemic } \\
\text { corticosteroids for at least three days, or an emergency department visit and /or hospitalisation due to asthma requiring systemic } \\
\text { corticosteroids; CART classification and regression tree; ED Emergency department visit; FEV1 Forced Expiratory Volume in } 1 \text { second; HOS } \\
\text { hospitalisation; N.R. not reported; OCS oral corticosteroids; PEF peak expiratory flow; RCT: randomised controlled trial; SAE serious } \\
\text { adverse event (this model was not validated, as exacerbations were not otherwise defined in the relevant report); SCS systemic } \\
\text { corticosteroids (including OCS); UV, unplanned visit }\end{array}$} \\
\hline
\end{tabular}

*This table shows summary details for 24 prediction models from the 12 reports identified in the systematic review. More details about the models are available in Table E2.

Large variation was observed in the derivation populations in terms of sample size (varying from 70 to $>50,000$ patients) and eligibility criteria for study participants. Furthermore, we found considerable differences in the definition of predicted outcomes (exacerbations), mostly consisting of one or more of the following: courses of systemic corticosteroids, emergency department (ED) visits and/or hospitalisations for asthma symptoms. The prediction time horizon varied from 4.6 to 30 months, although most reports $(n=7)$ used 12 months. Identified models included 3 to 34 predictors. Previous healthcare utilisation was the dominant category of predictors, with a course of systemic corticosteroids $(n=5), E D$ visits $(n=6)$ and previous hospitalisation $(n=6)$ the most frequently included (table 2); only 
two/12 reports described models not containing any measure of healthcare utilisation. Symptoms, whether or not applied as a symptom score were the second most commonly retained category of predictor, with only three reports (derived from administrative databases) lacking symptoms in their models. Finally, spirometry values were included in more than half $(n=6)$ of the reports. Most other identified predictors were used in a model only once or twice across the 12 reports.

Table 2: overview of predictors in identified reports $(n=12)^{*}$ 


\begin{tabular}{|c|c|c|c|c|c|c|c|c|c|c|c|c|c|}
\hline \multirow[b]{2}{*}{ Predictor } & \multicolumn{13}{|c|}{ Reference } \\
\hline & $\begin{array}{l}\text { Loy } \\
\text { man } \\
\text { s et } \\
\text { al } \\
2016 \\
{[18]}\end{array}$ & $\begin{array}{l}\text { Bate } \\
\text { man } \\
\text { et } \\
\text { al } \\
2014 \\
{[7]}\end{array}$ & $\begin{array}{l}\text { Eisne } \\
\text { r et } \\
\text { al } \\
2012 \\
{[23]}\end{array}$ & $\begin{array}{l}\text { Sato } \\
\text { et al } \\
2009 \\
{[24]}\end{array}$ & $\begin{array}{l}\text { Osbo } \\
\text { rne } \\
\text { et } \\
\text { al } \\
2007 \\
{[6]}\end{array}$ & $\begin{array}{l}\text { Mille } \\
\text { r et } \\
\text { al } \\
2006 \\
{[8]}\end{array}$ & $\begin{array}{l}\text { Pete } \\
\text { rs et } \\
\text { al } \\
2006 \\
{[25]}\end{array}$ & $\begin{array}{c}\text { Yurk } \\
\text { et al } \\
2004 \\
{[30]}\end{array}$ & $\begin{array}{l}\text { Scha } \\
\text { tz et } \\
\text { al } \\
2003 \\
{[26]}\end{array}$ & $\begin{array}{l}\text { Lieu } \\
\text { et al } \\
1999 \\
{[27]}\end{array}$ & $\begin{array}{l}\text { Ellm } \\
\text { an et } \\
\text { al } \\
1997 \\
{[28}\end{array}$ & $\begin{array}{l}\text { Gran } \\
\text { a et } \\
\text { al } \\
1997 \\
{[29]}\end{array}$ & Total \\
\hline \multicolumn{14}{|l|}{ Demographics } \\
\hline age & & & & & & $\sqrt{ }$ & $\mathrm{V}$ & $\sqrt{ }$ & & & $\sqrt{ }$ & $\sqrt{ }$ & 5 \\
\hline sex & & & & & & V & & $\sqrt{ }$ & & & & $\mathrm{V}$ & 3 \\
\hline income & & & & & & & & & $\mathrm{V}$ & & & & 1 \\
\hline race & & & & & & $\sqrt{ }$ & & $\sqrt{ }$ & & & & & 2 \\
\hline education & & & & & $\sqrt{ }$ & & & $\sqrt{ }$ & & & & & 2 \\
\hline \multicolumn{14}{|l|}{ Clinical } \\
\hline body mass index & & $\mathrm{V}$ & & & & $\sqrt{ }$ & & & & & & & 2 \\
\hline duration of asthma & & & & & & & & & & & & $\mathrm{V}$ & 1 \\
\hline treatment step & & $\sqrt{ }$ & & & & & & & & & & $\sqrt{ }$ & 2 \\
\hline reliever use & & $\sqrt{ }$ & & & & & & & & & & & 1 \\
\hline \multicolumn{14}{|l|}{ Symptoms } \\
\hline day time & & & V & & & & & $\sqrt{ }$ & & & & & 2 \\
\hline night time & & & $\sqrt{ }$ & & $\sqrt{ }$ & $\sqrt{ }$ & & & & & & & 3 \\
\hline on waking & & & & & & & & & & & $\sqrt{ }$ & & 1 \\
\hline limitation in activities & & & & & $\sqrt{ }$ & & & $\sqrt{ }$ & & & & & 2 \\
\hline seasonal & & & & & V & & & & & & & & 1 \\
\hline \multicolumn{14}{|l|}{ Symptom scores } \\
\hline $\mathrm{ACQ}$ & V & $\mathrm{v}$ & & & & & & & & & & & 2 \\
\hline ACT & & & $\sqrt{ }$ & $\mathrm{V}$ & & & & & & & & & 2 \\
\hline ATAQ & & & & & & & $\mathrm{V}$ & & & & & & 1 \\
\hline \multicolumn{14}{|l|}{ Comorbidity } \\
\hline allergies & & & & & $\mathrm{V}$ & & & & & & & & 1 \\
\hline previous pneumonia & & & & & & $\sqrt{ }$ & & & & & & & 1 \\
\hline diabetes & & & & & & V & & & & & & & 1 \\
\hline cataract & & & & & & $\sqrt{ }$ & & & & & & & 1 \\
\hline sinusitis & V & & & & & & & & & & & & 1 \\
\hline COPD & & & & & & & & $\sqrt{ }$ & & & & $\mathrm{V}$ & 2 \\
\hline coronary disease & & & & & & & & $\sqrt{ }$ & & & & $\sqrt{ }$ & 2 \\
\hline $\begin{array}{l}\text { Gastrointestinal } \\
\text { bleeding }\end{array}$ & & & & & & & & $\mathrm{V}$ & & & & & 1 \\
\hline \multicolumn{14}{|l|}{ Exposures } \\
\hline owns cat/dog & & & & & $\sqrt{ }$ & & & & & & & & 1 \\
\hline smoking & $\mathrm{V}$ & & & & & & & & & & & & 1 \\
\hline \multicolumn{14}{|l|}{ Previous utilisation } \\
\hline SCS & V & & V & & & V & & & $\mathrm{V}$ & $\sqrt{ }$ & & & 5 \\
\hline ED-visits & & & & & $\sqrt{ }$ & $\sqrt{ }$ & $\sqrt{ }$ & $\sqrt{ }$ & & $\sqrt{ }$ & & $\sqrt{ }$ & 6 \\
\hline hospitalisation & $\sqrt{ }$ & & $\sqrt{ }$ & & $\sqrt{ }$ & & & & $\sqrt{ }$ & & 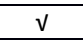 & $\sqrt{ }$ & 6 \\
\hline scheduled visits & & & & & & $\sqrt{ }$ & & $\sqrt{ }$ & & & & & 2 \\
\hline unplanned care & & & & & $\sqrt{ }$ & & $\mathrm{V}$ & & & & & V & 3 \\
\hline ICU/intubation & & & $\sqrt{ }$ & & & $\sqrt{ }$ & & & & & & & 2 \\
\hline \multicolumn{14}{|l|}{ Medication } \\
\hline $\begin{array}{l}>5 \text { asthma } \\
\text { medications }\end{array}$ & & & & & & & & $\sqrt{ }$ & & $\sqrt{ }$ & & & 1 \\
\hline ICS/LABA ratio & & & & & & & & V & & $\mathrm{V}$ & & & 1 \\
\hline nebuliser & & & $\sqrt{ }$ & & & $\sqrt{ }$ & & & & & & & 2 \\
\hline Methyl xanthine use & & & & & & & & $\sqrt{ }$ & & & & & 1 \\
\hline \multicolumn{14}{|l|}{ Additional tests } \\
\hline skin prick test & & & & & $\mathrm{V}$ & & & & & & & & 1 \\
\hline spirometry & $\sqrt{ }$ & $\sqrt{ }$ & $\sqrt{ }$ & $\mathrm{V}$ & $\sqrt{ }$ & $\sqrt{ }$ & & & & & & & 6 \\
\hline FeNO & $\mathrm{V}$ & & & V & & & & & & & & & 2 \\
\hline \multicolumn{14}{|l|}{ Other } \\
\hline perceived health & & & & & & $\sqrt{ }$ & & $\sqrt{ }$ & & & & & 2 \\
\hline insurance status & & & & & & & & & & & & $\sqrt{ }$ & 1 \\
\hline \multicolumn{14}{|c|}{$\begin{array}{l}\text { ACQ, asthma control questionnaire; ACT, asthma control test; ATAQ, asthma therapy assessment questionnaire; ED, emergency } \\
\text { department visit; FeNO fraction of exhaled nitric oxide; ICS, inhaled corticosteroids; ICU, intensive care unit admission; LABA, long-acting } \\
\text { beta agonists; SCS, systemic corticosteroids (including oral corticosteroids) } \\
\text { *When more than one model was reported, the one containing the most predictors is summarised in this table. }\end{array}$} \\
\hline
\end{tabular}


The quality of reporting was generally limited, hampering a proper assessment of risk of bias (figure 2). A large proportion of the reports lacked essential information: the majority did not describe missing values and handling thereof. Also, variable selection procedures and the number of events per variable, ${ }^{9}$ were poorly described. Documentation on measures of predictive performance was scarce: six/12 of the reports assessed discrimination, and three ${ }^{7,18,29}$ assessed measures of calibration. The observed inconsistency in defining exacerbations was deemed at high risk of bias, as were some assumptions of model development: three/12 studies were based on ten or more exacerbations per variable used as a candidate variable for the final model..$^{9}$

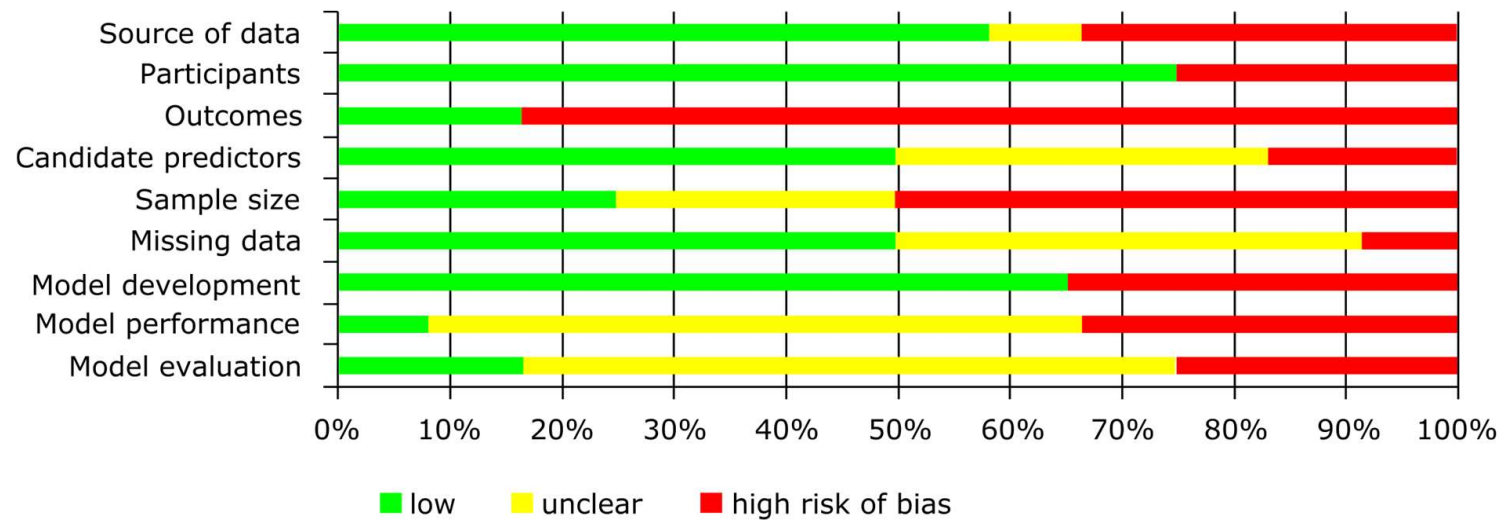

Figure 2: summarised risk of bias in identified reports based on CHecklist for critical Appraisal and data extraction for systematic Reviews of prediction Modelling Studies (CHARMS) criteria [13]

Overall, discriminative performance as expressed by the AUROC of the models for the author-defined outcomes was better in the ACCURATE population (mean 0.71; range 0.460.88) than in the U-BIOPRED population (mean 0.60; range 0.50-0.69; table 3 ). When assessing ATS/ERS-defined severe exacerbations, the mean AUROC in the ACCURATE population decreased to 0.65 , whereas it remained similar (mean 0.62) in the U-BIOPRED 
population. In the ACCURATE population however, some models had a better AUROC than documented in the original report (table 3)..$^{8,23,26}$ In particular, models using Classification And Regression Tree (CART) methods discriminated poorly (AUROC < 0.60) in both populations. The agreement between observed and predicted risks of exacerbation (calibration) was generally very limited, with exception of Eisner oral corticosteroids \& unplanned visit models, ${ }^{23}$ Loymans spirometry \& FeNO models ${ }^{18}$ in U-BIOPRED, and Ellman model $^{28}$ in ACCURATE (figure 3, Table E3, Figure E1). Calibration was similar across both ACCURATE and U-BIOPRED populations for most (14/23) comparisons (Figure E2); in three comparisons calibration was clearly different.

To get a sense of how well the given predictors in the published models might perform ideally, we derived new intercepts and slopes by simply fitting new models on ACCURATE and U-BIOPRED patients using the given predictors. To reduce complexity, we used the ATS/ERS definitions only. On average, AUROCs hardly improved as compared to the external validation in which one applies published predictors with intercept and slopes copied from their respective derivation cohort (median improvement of AUROC 0.02 and 0.01 in ACCURATE and U-BIOPRED, respectively; ranges: 0.01-0.06 and 0.00-0.10), suggesting that model recalibration would seldom yield much better predictive performance.

Table 3: results of external validation in two clinically distinct populations: AUROC (discrimination) 


\begin{tabular}{|c|c|c|c|c|c|c|c|}
\hline \multirow[b]{2}{*}{$\begin{array}{l}1^{\text {st }} \text { author / } \\
\text { year } \\
\text { [reference] }\end{array}$} & \multirow[b]{2}{*}{ Model } & \multirow[b]{2}{*}{$\begin{array}{l}\text { Author } \\
\text { defined } \\
\text { outcome* }\end{array}$} & \multirow[b]{2}{*}{$\begin{array}{l}\text { Original } \\
\text { AUROC }\end{array}$} & \multicolumn{2}{|c|}{$\begin{array}{l}\text { Primary care validation population } \\
\text { (ACCURATE) }\end{array}$} & \multicolumn{2}{|c|}{$\begin{array}{l}\text { Secondary care validation population } \\
\text { (U-BIOPRED) }\end{array}$} \\
\hline & & & & $\begin{array}{l}\text { Author defined } \\
\text { outcome }\end{array}$ & $\begin{array}{l}\text { ATS/ERS severe } \\
\text { exacerbations }\end{array}$ & $\begin{array}{l}\text { Author defined } \\
\text { outcome }\end{array}$ & $\begin{array}{l}\text { ATS/ERS severe } \\
\text { exacerbations }\end{array}$ \\
\hline \multirow[t]{3}{*}{$\begin{array}{l}\text { Loymans et } \\
\text { al } 2016 \text { [18] }\end{array}$} & History & $\begin{array}{l}\text { ATS/ERS } \\
\text { severe } \\
\text { exacerbation }\end{array}$ & 0.77 & & $t$ & & $\begin{array}{l}0.69 \\
(0.63-0.75)\end{array}$ \\
\hline & $\begin{array}{l}\text { History + } \\
\text { spirometry }\end{array}$ & $\begin{array}{l}\text { ATS/ERS } \\
\text { severe } \\
\text { exacerbation }\end{array}$ & 0.79 & & $t$ & & $\begin{array}{l}0.69 \\
(0.63-0.75)\end{array}$ \\
\hline & $\begin{array}{l}\text { History + } \\
\text { spirometry } \\
+ \text { FeNO }\end{array}$ & $\begin{array}{l}\text { ATS/ERS } \\
\text { severe } \\
\text { exacerbation }\end{array}$ & 0.80 & & + & & $\begin{array}{l}0.69 \\
(0.63-0.75)\end{array}$ \\
\hline $\begin{array}{l}\text { Bateman et } \\
\text { al } 2015 \text { [7] }\end{array}$ & RSE & $\begin{array}{l}\text { ATS/ERS } \\
\text { severe } \\
\text { exacerbation }\end{array}$ & n.r. & & $\begin{array}{l}0.72 \\
(0.65-0.78)\end{array}$ & & $\begin{array}{l}0.64 \\
(0.58-0.70)\end{array}$ \\
\hline \multirow[t]{5}{*}{$\begin{array}{l}\text { Eisner et al } \\
2012[23] \\
\end{array}$} & OCS & OCS & 0.69 & $\begin{array}{l}0.72 \\
(0.66-0.79)\end{array}$ & $\begin{array}{l}0.75 \\
(0.69-0.81)\end{array}$ & $\begin{array}{l}0.59 \\
(0.52-0.66)\end{array}$ & $\begin{array}{l}0.66 \\
(0.60-0.72)\end{array}$ \\
\hline & $\mathrm{ED}$ & $E D$ & 0.75 & $\begin{array}{l}0.87 \\
(0.79-0.96)\end{array}$ & $\begin{array}{l}0.77 \\
(0.71-0.82)\end{array}$ & $\begin{array}{l}0.69 \\
(0.56-0.81)\end{array}$ & $\begin{array}{l}0.64 \\
(0.58-0.71)\end{array}$ \\
\hline & HOS & HOS & 0.69 & $\begin{array}{l}0.79 \\
(0.64-0.94)\end{array}$ & $\begin{array}{l}0.74 \\
(0.68-0.80)\end{array}$ & $\begin{array}{l}0.62 \\
(0.53-0.72)\end{array}$ & $\begin{array}{l}0.65 \\
(0.59-0.71)\end{array}$ \\
\hline & UV & UV & 0.68 & $\begin{array}{l}0.75 \\
(0.64-0.86)\end{array}$ & $\begin{array}{l}0.76 \\
(0.70-0.81)\end{array}$ & $\begin{array}{l}0.52 \\
(0.43-0.61)\end{array}$ & $\begin{array}{l}0.65 \\
(0.59-0.71)\end{array}$ \\
\hline & SAE & SAE & 0.78 & \multicolumn{4}{|c|}{$\begin{array}{l}\text { Not assessed: not able to be operationalised as exacerbations were defined only } \\
\text { as serious adverse events }\end{array}$} \\
\hline $\begin{array}{l}\text { Sato et al } \\
2009[24]\end{array}$ & & $\begin{array}{l}\text { OCS/ED/HOS/ } \\
\text { FEV1 decline }\end{array}$ & 0.63 & $\ddagger$ & $\begin{array}{l}0.57 \\
(0.50-0.65)\end{array}$ & $\mp$ & $\begin{array}{l}0.50 \\
(0.44-0.56)\end{array}$ \\
\hline \multirow[t]{3}{*}{$\begin{array}{l}\text { Osborne } \\
2007 \text { [6] } \\
\end{array}$} & PAR-A & ED/HOS/UV & n.r. & $\begin{array}{l}0.56 \\
(0.42-0.71)\end{array}$ & $\begin{array}{l}0.63 \\
(0.57-0.70)\end{array}$ & $\begin{array}{l}0.59 \\
(0.52-0.65)\end{array}$ & $\begin{array}{l}0.60 \\
(0.54-0.66)\end{array}$ \\
\hline & PAR-B & $\mathrm{ED} / \mathrm{HOS} / \mathrm{UV}$ & n.r. & $\begin{array}{l}0.68 \\
(0.57-0.79)\end{array}$ & $\begin{array}{l}0.65 \\
(0.58-0.72)\end{array}$ & $\begin{array}{l}0.53 \\
(0.46-0.59)\end{array}$ & $\begin{array}{l}0.61 \\
(0.55-0.67)\end{array}$ \\
\hline & PAR-C & ED/HOS/UV & n.r. & $\begin{array}{l}0.65 \\
(0.54-0.77)\end{array}$ & $\begin{array}{l}0.65 \\
(0.58-0.71)\end{array}$ & $\begin{array}{l}0.53 \\
(0.46-0.60)\end{array}$ & $\begin{array}{l}0.61 \\
(0.55-0.67)\end{array}$ \\
\hline \multirow[t]{3}{*}{$\begin{array}{l}\text { Miller et al } \\
2006 \text { [8] }\end{array}$} & TENOR & ED/HOS & 0.78 & $\begin{array}{l}0.81 \\
(0.63-0.99)\end{array}$ & $\begin{array}{l}0.61 \\
(0.54-0.68)\end{array}$ & $\begin{array}{l}0.65 \\
(0.56-0.75)\end{array}$ & $\begin{array}{l}0.64 \\
(0.58-0.70)\end{array}$ \\
\hline & $+\mathrm{PRO}$ & ED/HOS & 0.80 & $\begin{array}{l}0.88 \\
(0.79-0.98)\end{array}$ & $\begin{array}{l}0.67 \\
(0.60-0.74)\end{array}$ & $\begin{array}{l}0.66 \\
(0.55-0.77)\end{array}$ & $\begin{array}{l}0.63 \\
(0.57-0.69)\end{array}$ \\
\hline & $+\mathrm{HCU}$ & ED/HOS & 0.82 & $\begin{array}{l}0.88 \\
(0.77-1.00)\end{array}$ & $\begin{array}{l}0.68 \\
(0.61-0.75)\end{array}$ & $\begin{array}{l}0.66 \\
(0.55-0.77)\end{array}$ & $\begin{array}{l}0.62 \\
(0.56-0.68)\end{array}$ \\
\hline \multirow[t]{2}{*}{$\begin{array}{l}\text { Peters et al } \\
2006 \text { [25] }\end{array}$} & Model 1 & ED/HOS/UV & n.r. & $\begin{array}{l}0.72 \\
(0.64-0.80)\end{array}$ & $\begin{array}{l}0.65 \\
(0.59-0.71)\end{array}$ & $\begin{array}{l}0.58 \\
(0.51-0.65)\end{array}$ & $\begin{array}{l}0.53 \\
(0.47-0.59)\end{array}$ \\
\hline & Model 2 & ED/HOS/UV & n.r. & $\begin{array}{l}0.72 \\
(0.62-0.82)\end{array}$ & $\begin{array}{l}0.59 \\
(0.53-0.65)\end{array}$ & $\begin{array}{l}0.57 \\
(0.50-0.65) \\
\end{array}$ & $\begin{array}{l}0.58 \\
(0.52-0.64) \\
\end{array}$ \\
\hline $\begin{array}{l}\text { Yurk et al } \\
2004[30]\end{array}$ & & $\begin{array}{l}\text { ED/HOS/lost } \\
\text { activity days }\end{array}$ & 0.78 & $\ddagger$ & $\begin{array}{l}0.62 \\
(0.56-0.69)\end{array}$ & $\ddagger$ & $\begin{array}{l}0.60 \\
(0.54-0.66)\end{array}$ \\
\hline $\begin{array}{l}\text { Schatz et al } \\
2003[26]\end{array}$ & & HOS & 0.71 & $\begin{array}{l}0.77 \\
(0.64-0.90)\end{array}$ & $\begin{array}{l}0.68 \\
(0.61-0.75)\end{array}$ & $\begin{array}{l}0.63 \\
(0.54-0.72)\end{array}$ & $\begin{array}{l}0.63 \\
(0.57-0.69)\end{array}$ \\
\hline \multirow[t]{2}{*}{$\begin{array}{l}\text { Lieu } \\
1999 \text { [27] }\end{array}$} & Model A & ED/HOS & n.r. & $\begin{array}{l}0.56 \\
(0.43-0.69)\end{array}$ & $\begin{array}{l}0.62 \\
(0.56-0.67)\end{array}$ & $\begin{array}{l}0.58 \\
(0.51-0.65)\end{array}$ & $\begin{array}{l}0.60 \\
(0.54-0.65)\end{array}$ \\
\hline & Model B & $\mathrm{ED} / \mathrm{HOS}$ & n.r. & $\begin{array}{l}0.46 \\
(0.36-0.57)\end{array}$ & $\begin{array}{l}0.39 \\
(0.34-0.44)\end{array}$ & $\begin{array}{l}0.52 \\
(0.46-0.59)\end{array}$ & $\begin{array}{l}0.55 \\
(0.50-0.59)\end{array}$ \\
\hline $\begin{array}{l}\text { Ellman et al } \\
1997[28]\end{array}$ & & OCS & n.r. & $\begin{array}{l}0.57 \\
(0.47-0.66)\end{array}$ & $\begin{array}{l}0.61 \\
(0.55-0.67)\end{array}$ & $\begin{array}{l}0.50 \\
(0.41-0.60)\end{array}$ & $\begin{array}{l}0.59 \\
(0.53-0.65)\end{array}$ \\
\hline $\begin{array}{l}\text { Grana et al } \\
1997 \text { [29] }\end{array}$ & & HOS & n.r. & Not assessed: to & ny missing variab & & \\
\hline \multicolumn{8}{|c|}{$\begin{array}{l}\text { * ED, emergency department visit; HOS, hospitalisation; OCS, systemic corticosteroids; UV, unplanned visit; SAE, serious adverse event. } \\
\text { American Thoracic Society/European Respiratory Society defined severe exacerbation: systemic corticosteroids for at least } 3 \text { days, ED visit } \\
\text { and/or hospitalisation requiring systemic corticosteroids [15]. Numbers in parenthesis are } 95 \% \text { confidence intervals. } \\
+ \text { Not assessed: model was derived from this population } \\
\text { ‡ outcome included a variable that was not available in the validation sets, therefore this model was only validated for ATS/ERS defined severe } \\
\text { exacerbations. }\end{array}$} \\
\hline
\end{tabular}



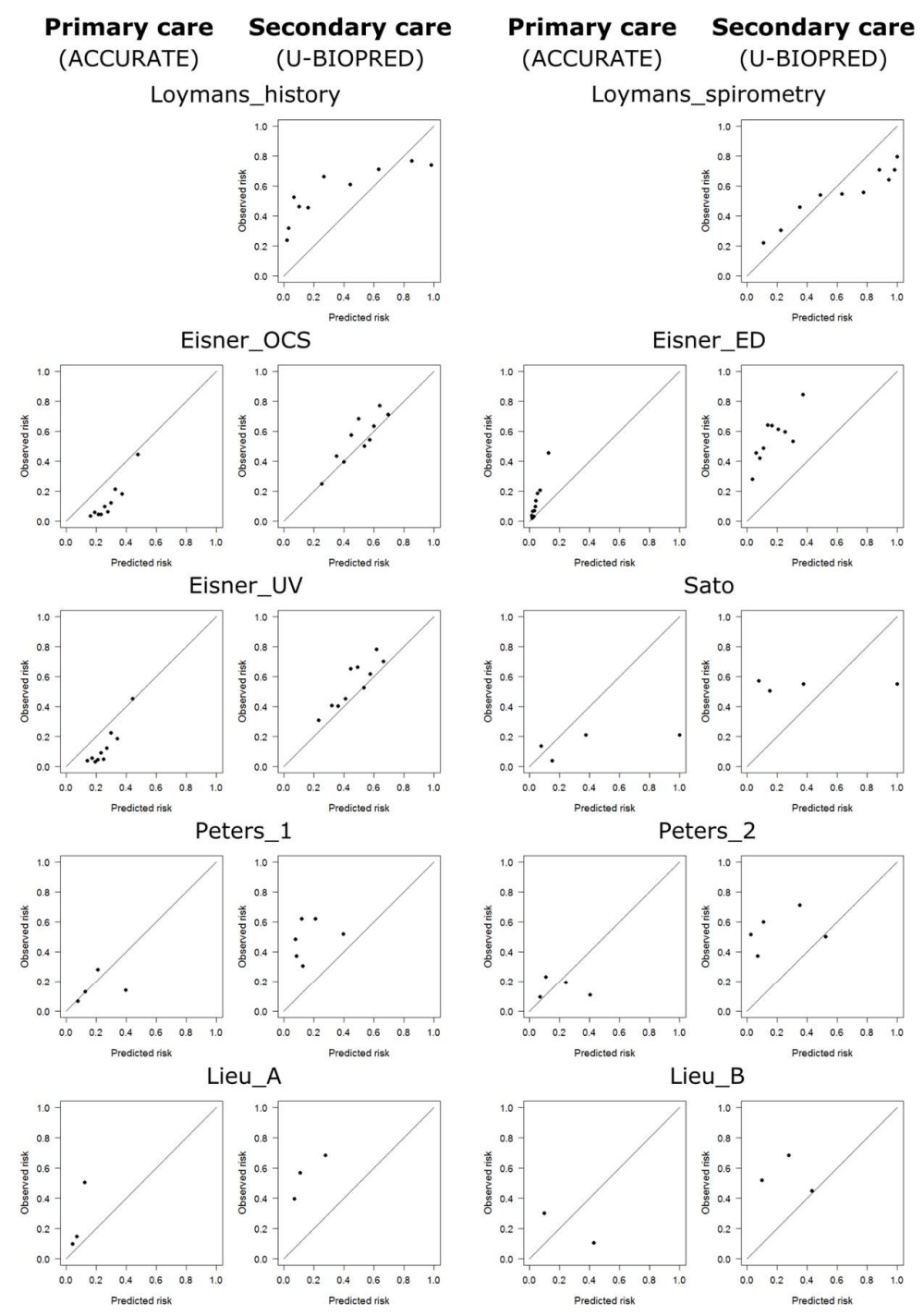
Primary care Secondary care
(ACCURATE) (U-BIOPRED)
Loymans_FeNO

Loymans_spirometry
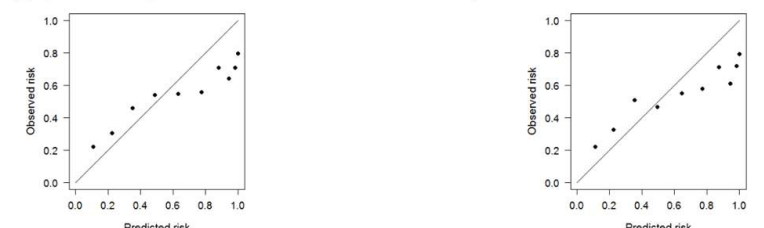

Eisner_ED
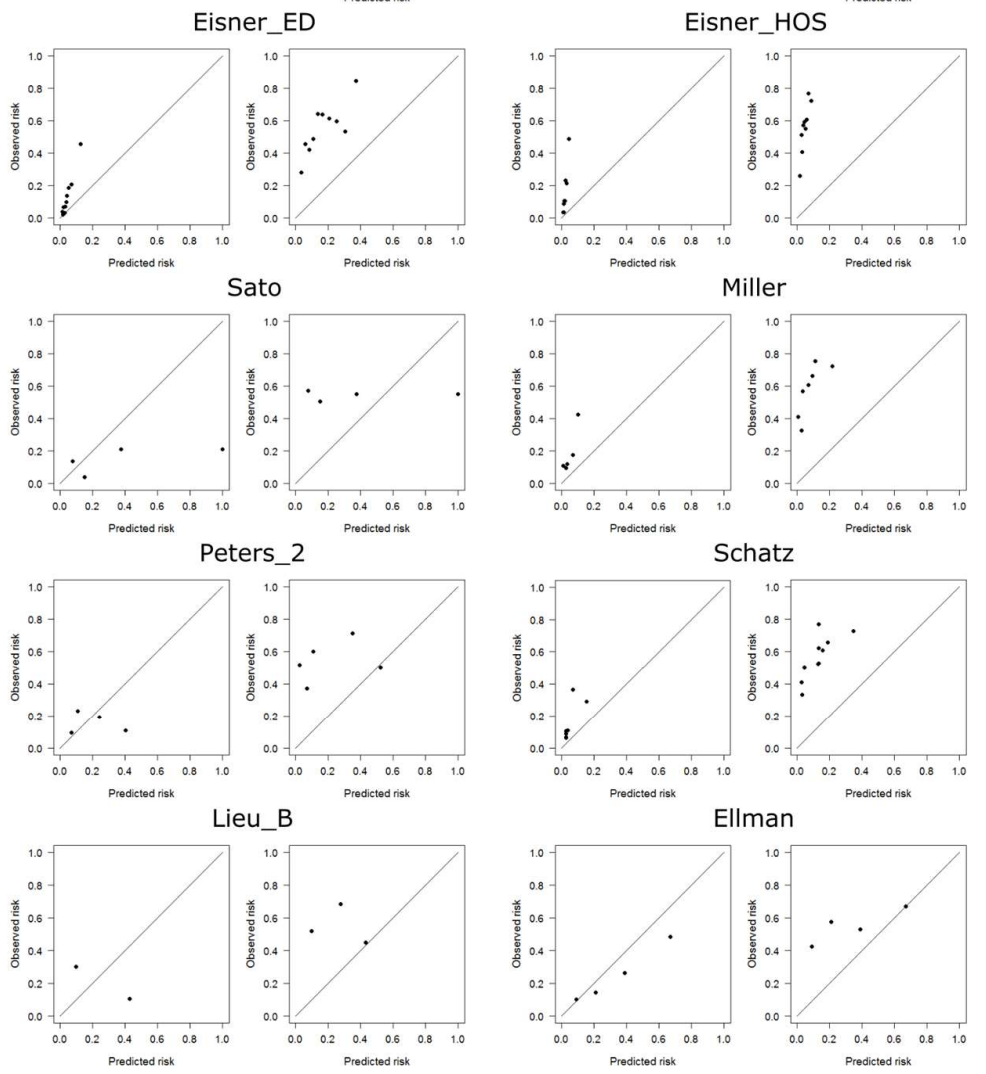

Figure 3: calibration plots for validated models, on ATS/ERS severe exacerbation[15] outcomes

Calibration plots were drawn for all validated prediction models (except 7/22 merely reporting on risk scores) in the primary care (ACCURATE) and secondary care (U-BIOPRED) cohorts. Each dot represents a sample of patients in which the fraction of patients with observed events ( $y$-axis) is plotted against the mean predicted events ( $x$-axis). Systematic under-prediction (estimated risks too low; indicated by dots above the line is often observed (for example Eisner_ED). Some models (Eisner_HOS, Miller) failed to predict ATS/ERS severe exacerbation outcomes: although there were observed events (spread of dots along the $y$ axis), they did not calculate risks (no spread along the $x$-axis).

ED, emergency department-visit; HOS, hospitalisation; OCS, systemic corticosteroids; UV, unplanned visit 


\section{Discussion}

In this study, we identified 24 published models for the prediction of exacerbations of asthma in adults, and carried out external validation of 22 of these models in two distinct datasets, a primary care trial cohort (ACCURATE) and a secondary care cohort (U-BIOPRED). The models included in this review were developed in populations across the spectrum of asthma severity and used different definitions of exacerbations. Despite these differences, a history of healthcare utilisation, symptoms and spirometry were often retained in the final models. No single model outperformed the others in predictive properties. Discriminative properties were modest and similar in both populations when predicting standardised ATS/ERS-defined severe exacerbations. In general, calibration was poor, as indicated by systematic over- or under-prediction. Predictive properties of most models were comparable in the two distinct validation populations, suggesting that the construction of a generalizable model predicting severe exacerbations in adults may be feasible.

External validation of prediction models for exacerbations is scarce; only two of the 12 reports, ${ }^{18,23}$ which were included in this review, describe such an effort. Two narrative reviews, focussing on factors associated with exacerbations rather than multivariable models predicting these outcomes in individual patients, ${ }^{10,13}$ also identified items from healthcareutilisation, symptoms and spirometry as important predictors for severe asthma exacerbations. A variety of other factors, for example blood eosinophils, have been identified as biomarkers associated with severe exacerbations. ${ }^{1}$ With the exception of FeNO, our review did not identify any prediction models containing biomarkers; they were not assessed as candidate predictors in the studies we retrieved. Nevertheless, in COPD, blood biomarkers do not seem to have large predictive value on top of clinical markers. ${ }^{31}$ 
A strength of this study is that, with one exception, ${ }^{18}$ the external validation was performed by investigators independent of the original study. External validation tends to be too optimistic when performed by investigators involved with the development of a model. ${ }^{32,33}$ Secondly, we evaluated the validity of identified models in two separate populations with different characteristics, acknowledging the clinical heterogeneity of asthma populations and enabling the assessment of the models' transportability (i.e. preservation of predictive performance across different populations)..$^{20,34} \mathrm{~A}$ potential concern of the observed heterogeneity among the populations in which the models were derived, may be that the derivation cohorts are not sufficiently consistent with (one of) the two validation populations. However, the more agreement between the derivation and the validation population, the less generalizable the predictive properties will be. Notably, models derived from severe asthma populations (Risk Score for Exacerbations ${ }^{7}$ and TENOR risk score ${ }^{8}$ ) did not perform better in the severe asthma (U-BIOPRED) population. Finally, we assessed predictive capacities of author-defined outcomes as well as the current standard definition of severe exacerbations according to the ATS/ERS recommendations over 12 months. ${ }^{15} \mathrm{~A}$ limitation of this study is that we rejected a significant proportion of the identified reports identified from the literature search, including some large high quality studies, ${ }^{35,36}$ because they corrected for covariates or reported only on relative risks. These studies, of which some were included in previous reviews, ${ }^{10,13}$ appear to have been designed to assess the independent contribution of each of several predictors, instead of determining the predictive performance of an optimal combination of predictors in individual patients, which was our goal. Models calculating absolute risks can assist practitioners directly, for example when exacerbation risk exceeds a certain cut off value, the practitioner may decide to 
increase asthma therapy. This information is less clear from models reporting odds ratios: then the practitioner merely knows the in- or decreased risk of a patient with one or more characteristics as compared to patients without those characteristics. Second, one of the validation sets (the ACCURATE population) did not include $>=100$ events, as recommended for use in external validations. ${ }^{37}$ Even though this was a trial population, we believe it was suitable as a validation population since both randomised trials and prospective cohorts can be used for prediction modelling. ${ }^{14}$ Additionally, this pragmatic trial (in which the intervention was aiming for partly or strictly controlled asthma using the Dutch asthma treatment guidelines, thus mimicking usual care) had only few restrictive eligibility criteria for inclusion and differences in exacerbation outcomes were non-significant. ${ }^{16}$ Finally, we assessed exacerbations as the only marker of future risk for adverse outcomes, whereas GINA also mentions medication side effects and accelerated lung function decline as additional adverse outcomes of clinical importance. The latter outcome however, is infrequently reported in current literature but may be related with exacerbations in patients not treated with inhaled corticosteroids. ${ }^{38,39}$

Previous healthcare-utilisation, symptoms, and spirometry values were amongst the most frequently identified predictors of exacerbations in the studies we evaluated, emphasizing the importance and potential transportability of these predictors. They were retained in the majority of the models after a selection process performed in different populations, where they competed for preservation in the models with other, less often preserved items. Some models tended to discriminate better in the ACCURATE population than in the original development populations, possibly due to the large $(r)$ variability in predictor values in the 
patient mix of ACCURATE. In this primary care population, patients treated by specialists were also eligible, ${ }^{16}$ resulting in a broad spectrum of asthma severity.

Nevertheless, the predictive capacities of current models leave room for improvement: discrimination was generally limited and most prediction models demonstrated substantial miscalibration. This was probably related to differences between exacerbation rates, reflecting differences in asthma severity between development- and validation populations (spectrum transportability). Other factors limiting transportability of prediction models across populations are historical, methodological, geographical and follow-up interval differences, ${ }^{34}$ all present in the models we evaluated. There are several model updating techniques available aimed at improving the predictive performance of previously developed prediction models in new populations. ${ }^{40}$ These include recalibration (adjusting the model's intercept and/or slope), model revision (re-estimating the strength of the predictors) and model extension. Model extension (adding predictors to an existing model), should preferably be performed with variables having a different relation to exacerbations. Variables that were retained only once or twice in the identified prediction models (table 2) seem less suitable as candidate predictors. It is likely that a marker of inflammation type, such as blood eosinophils, may be a potential new candidate, as it has demonstrated to be related to exacerbations. ${ }^{36,41}$ Other conceivable biomarkers are periostin and dipeptidyl peptidase-4. These markers may have different predictive capacities in different asthma phenotypes or endotypes, possibly facilitating the development of prediction models for phenotype- or endotype specific populations.

The predictive capacities of models that were derived from a diversity of populations were comparable in the two validation populations, reflecting extremes of the asthma severity spectrum (with $13 \%$ vs $55 \%$ patients respectively experiencing exacerbations). Relevant 
predictor-categories (previous healthcare-utilisation, symptoms, and spirometry values) thus appear independent of population characteristics, suggesting that the construction of a generally applicable prediction model for severe exacerbations of asthma may be feasible. From all identified models, no single model was preferred above the others after assessing predictive performance. Although some models showed better discrimination, ${ }^{8}$ or better calibration, ${ }^{23}$ none of the models is suitable for immediate application in clinical practice without tailoring to the specific target population. This need for tailoring to specific populations is clearly a limitation. The present findings merit the development of more generalizable models that can be implemented without the need for further adjustments. Access to individual patient data from multiple settings may help to address this issue. ${ }^{42}$ To avoid duplication of work that has already been done by others, ${ }^{43}$ we suggest that the starting point should be an existing prediction model (or at least the identified core-set of predictors, with symptoms preferably as a symptom score, ${ }^{10}$ spirometry as continuous FEV1\%predicted ${ }^{14}$ and healthcare utilization as a course of systemic corticosteroids in the previous year) that would be modified or extended with new predictors. For the latter, biomarkers for inflammation-type or asthma phenotype seem suitable potential predictors. Ultimately, a clinical impact study should demonstrate the models' added value in clinical decision making before application in practice. ${ }^{44}$

In current prediction models for exacerbations of asthma, derived from different populations, healthcare-utilisation, symptoms, and spirometry values are predictors most commonly preserved. The predictive properties of most identified models were similar in two clinically distinct validation populations, suggesting that the construction of a generalizable model predicting exacerbations of asthma is feasible. Nevertheless, the predictive capacities of current models leave room for improvement, as discrimination and 
calibration were usually below the desired level: none of the models reviewed here can be implemented in clinical practice straightforwardly. Updating existing models containing at least the preserved predictors and extending them with new markers covering a different relation to exacerbation risk should be the focus of future research.

\section{Acknowledgements}

We thank Rene Spijker of the Academic Medical Center - University of Amsterdam /

Cochrane Netherlands for his assistance in searching the literature. We also thank the U-

BIOPRED study group (appendix VI) for sharing data.

\section{References}

1 Global Initiative for Asthma. Global Strategy for Asthma Management and Prevention, 2017. Available from: www.ginasthma.org

2 Taylor DR, Bateman ED, Boulet LP, Boushey HA, Busse WW, Casale TB, et al. A new perspective on concepts of asthma severity and control. Eur Respir J 2008;32:545-54.

3 Juniper EF, O'Byrne PM, Guyatt GH, Ferrie PJ, King DR. Development and validation of a questionnaire to measure asthma control. Eur Respir J 1999;44:902-07.

$4 \quad$ Nathan RA, Sorkness CA, Kosinski M, Schatz M, Li JT, Marcus P, et al. Development of the asthma control test: a survey for assessing asthma control. J Allergy Clin Immunol 2004;113:59-65.

5 Reddel HK, Bateman ED, Becker A, Boulet LP, Cruz AA, Drazen JM, et al. A summary of the new GINA strategy: a roadmap to asthma control. Eur Respir J 2015;46:622-39.

6 Osborne ML, Pedula KL, O'Hollaren M, Ettinger KM, Stibolt T, Buist AS, et al. Assessing future need for acute care in adult asthmatics: the Profile of Asthma Risk Study: a prospective health maintenance organization-based study. Chest 2007;132:1151-61.

7 Bateman ED, Buhl R, O'Byrne PM, Humbert M, Reddel HK, Sears MR, et al. Development and validation of a novel risk score for asthma exacerbations: The risk score for exacerbations. J Allergy Clin Immunol 2015;135:1457-64.e4. 
$8 \quad$ Miller MK, Lee JH, Blanc PD, Pasta DJ, Gujrathi S, Barron H, et al; TENOR Study Group. TENOR risk score predicts healthcare in adults with severe or difficult-to-treat asthma. Eur Respir J 2006;28:1145-55.

9 Bouwmeester W, Zuithoff NP, Mallett S, Geerlings MI, Vergouwe Y, Steyerberg EW, et al. Reporting and methods in clinical prediction research: a systematic review. PLoS Med 2012;9:1-12.

10 Greenberg S. Asthma exacerbations: predisposing factors and prediction rules. Curr Opin Allergy Clin Immunol 2013;13:225-36.

11 Ingui BJ, Rogers MA. Searching for Clinical Prediction Rules in MEDLINE. J Am Med Inform Assoc 2001;8:391-7.

12 Geersing GJ, Bouwmeester W, Zuithoff P, Spijker R, Leeflang M, Moons KG. Search filters for finding prognostic and diagnostic prediction studies in Medline to enhance systematic reviews. PLoS One 2012;7:e32844.

13 Sims EJ, Price D, Haughney J, Ryan D, Thomas M. Current control and future risk in asthma management. Allergy Asthma Immunol Res 2011;3:217-25.

14 Moons KGM, de Groot JAH, Bouwmeester W, Vergouwe Y, Mallett S, Altman DG, et al. Critical Appraisal and Data Extraction for Systematic Reviews of Prediction Modelling Studies: The CHARMS Checklist. PLoS Med 2014;11:e1001744.

15 Reddel HK, Taylor DR, Bateman ED, Boulet LP, Boushey HA, Busse WW et al; American Thoracic Society/European Respiratory Society Task Force on Asthma Control and Exacerbations. An official American Thoracic Society/European Respiratory Society statement: asthma control and exacerbations: standardizing endpoints for clinical asthma trials and clinical practice. Am J Respir Crit Care Med 2009;180:59-99.

16 Honkoop PJ, Loijmans RJ, Termeer EH, Termeer EH, Snoeck-Stroband JB, van den Hout WB, et al; Asthma Control Cost-Utility Randomized Trial Evaluation (ACCURATE) Study Group. Symptom- and fraction of exhaled nitric oxide-driven strategies for asthma control: A cluster-randomized trial in primary care. J Allergy Clin Immunol 2015;135:682-8.

17 Shaw DE, Sousa AR, Fowler SJ, Fleming LJ, Roberts G, Corfield J, et al; U-BIOPRED Study Group. Clinical and inflammatory characteristics of the European U-BIOPRED adult severe asthma cohort. Eur Respir J 2015;46:1308-21.

18 Loymans RJ, Honkoop PJ, Termeer EH, Snoeck-Stroband JB, Assendelft WJ, Schermer $T R$, et al. Identifying patients at risk for severe exacerbations of asthma: development and external validation of a multivariable prediction model. Thorax 2016;71:838-46.

19 Janssen KJ, Vergouwe Y, Donders AR, Harrell FE Jr, Chen Q, Grobbee DE, et al. Dealing with missing predictor values when applying clinical prediction models. Clin Chem 2009;55:994-1001. 
20 Debray TP, Vergouwe Y, Koffijberg H, Nieboer D, Steyerberg EW, Moons KG. A new framework to enhance the interpretation of external validation studies of clinical prediction models. J Clin Epidemiol 2015;68:279-89.

21 Steyerberg EW, Vickers AJ, Cook NR, Gerds T, Gonen M, Obuchowski N, et al. Assessing the Performance of Prediction Models: A Framework for Traditional and Novel Measures. Epidemiology 2010;21:128-38.

22 Blanc PD, Jones M, Besson C, Katz P, Yelin E. Work disability among adults with asthma. Chest 1993;104:1371-7.

23 Eisner MD, Yegin A, Trzaskoma B. Severity of asthma score predicts clinical outcomes in patients with moderate to severe persistent asthma. Chest 2012;141:58-65.

24 Sato R, Tomita K, Sano H, Ichihashi H, Yamagata S, Sano A, et al. The strategy for predicting future exacerbation of asthma using a combination of the Asthma Control Test and lung function test. J Asthma 2009;46:677-82.

25 Peters D, Chen C, Markson LE, Allen-Ramey FC, Vollmer WM. Using an asthma control questionnaire and administrative data to predict health-care utilization. Chest 2006;129:91824.

26 Schatz M, Cook EF, Joshua A, Petitti D. Risk factors for asthma hospitalizations in a managed care organization: development of a clinical prediction rule. Am J Manag Care 2003;9:538-47.

27 Lieu TA, Capra AM, Quesenberry CP, Mendoza GR, Mazar M. Computer-based models to identify high-risk adults with asthma: is the glass half empty of half full? J Asthma 1999;36:359-70.

28 Ellman MS, Viscoli CM, Sears MR, Taylor DR, Beckett WS, Horwitz RI. A new index of prognostic severity for chronic asthma. Chest 1997;112:582-90.

29 Grana J, Preston S, McDermott PD, Hanchak NA. The use of administrative data to risk-stratify asthmatic patients. Am J Med Qual 1997;12:113-19.

30 Yurk RA, Diette GB, Skinner EA, Dominici F, Clark RD, Steinwachs DM, et al. Predicting patient-reported asthma outcomes for adults in managed care. Am J Manag Care 2004;10:321-8.

31 Keene JD, Jacobson S, Kechris K, Kinney GL, Foreman MG, Doerschuk CM, et al; COPDGene and SPIROMICS Investigators. Biomarkers Predictive of Exacerbations in the SPIROMICS and COPDGene Cohorts. Am J Respir Crit Care Med 2017;195:473-81. 
32 Collins GS, de Groot JA, Dutton S, Omar O, Shanyinde M, Tajar A, et al. External validation of multivariable prediction models: a systematic review of methodological conduct and reporting. BMC Med Res Methodol 2014;14:40.

33 Siontis GC, Tzoulaki I, Castaldi PJ, Ioannidis JP. External validation of new risk prediction models is infrequent and reveals worse prognostic discrimination. J Clin Epidemiol 2015;68:25-34.

34 Justice AC, Covinsky KE, Berlin JA. Assessing the generalizability of prognostic information. Ann Intern Med 1999;130:515-24.

35 Blakey JD, Price DB, Pizzichini E, Popov TA, Dimitrov BD, Postma DS, et al. Identifying Risk of Future Asthma Attacks Using UK Medical Record Data: A Respiratory Effectiveness Group Initiative. J Allergy Clin Immunol Pract. 2017;5:1015-24e8.

36 Price D, Wilson AM, Chisholm A, Rigazio A, Burden A, Thomas M, et al. Predicting frequent asthma exacerbations using blood eosinophil count and other patient data routinely available in clinical practice. J Asthma Allergy 2016;9:1-12.

37 Vergouwe Y, Steyerberg EW, Eijkemans MJ, Habbema JD. Substantial effective sample sizes were required for external validation studies of predictive logistic regression models. J Clin Epidemiol 2005;58:475-83.

38 Bai TR, Vonk JM, Postma DS, Boezen HM. Severe exacerbations predict excess lung function decline in asthma. Eur Respir J 2007;30:452-6.

39 O'Byrne PM, Pedersen S, Lamm CJ, Tan WC, Busse WW; START Investigators Group. Severe exacerbations and decline in lung function in asthma. Am J Respir Crit Care Med 2009;179:19-24.

40 Janssen KJ, Moons KG, Kalkman CJ, Grobbee DE, Vergouwe Y. Updating methods improved the performance of a clinical prediction model in new patients. J Clin Epidemiol 2008;61:76-86.

41 Papaioannou Al, Kostikas K, Bakakos P, Papaporfyriou A, Konstantellou E, Hillas G,et al. Predictors of future exacerbation risk in patients with asthma. Postgrad Med 2016;128:687-92.

42 Debray TP, Riley RD, Rovers MM, Reitsma JB, Moons KG; Cochrane IPD Meta-analysis Methods group. Individual participant data (IPD) meta-analyses of diagnostic and prognostic modeling studies: guidance on their use. PLoS Med 2015;12:e1001886.

43 Damen JA, Hooft L, Schuit E, Debray TP, Collins GS, Tzoulaki I, et al. Prediction models for cardiovascular disease risk in the general population: systematic review. BMJ 2016;353:i2416. 
44 Toll DB, Janssen KJ, Vergouwe $\mathrm{Y}$, Moons KG. Validation, updating and impact of clinical prediction rules: a review. J Clin Epidemiol 2008;61:1085-94. 


\section{Appendix search syntax}

\section{Pubmed}

1. exp Asthma/

2. asthma.ti,ab,ot.

3. (Acute adj4 asthma).ti,ab,ot.

4. exacerbat*.ti,ab,ot.

5. 1 or 2

6. 4 and 5

7. (attack adj3 asthma).ti,ab,ot.

8.3 or 6 or 7

9. Validat\$.tw. or Predict\$.ti. or Rule\$.tw.

10. ((Predict\$ and (Outcome\$ or Risk\$ or Model\$)) or

((History or Variable\$ or Criteria or Scor\$ or

Characteristic\$ or Finding\$ or Factor\$) and (Predict\$ or Model\$ or Decision\$ or Identif\$ or Prognos\$))).tw.

11. (Decision\$.tw. and ((Model\$ or Clinical\$).tw. or exp Models, Statistical/)) or (Prognostic and (History or Variable\$ or Criteria or Scor\$ or Characteristic\$ or Finding\$ or Factor\$ or Model\$)).tw.

12. exp ROC Curve/

13. ("Stratification" or "Discrimination" or

"Discriminate" or "c-statistic" or "c statistic" or "Area under the curve" or "AUC" or "Calibration" or

"Indices" or "Algorithm" or "Multivariable").tw.

14. 9 or 10 or 11 or 12 or 13

15. exp Child/ or Pediatrics/ or Adolescent/ or Adult Children/ or Minors/ or adolescent, hospitalized/ or child, hospitalized/ or (child* or p? ediat* or boy*1 or girl*1 or schoolchild* or kid*1 or juvenil* or youth* or prepubescen* or prepubert* or schoolage* or school age* or teens or teen or teenage* or youth or youths or adolescen* or pubescen* or underage* or minors).tw,ot. or (child* or pediatric* or paediatric* or adolescen*).jw.

16. exp Adult/

17. adult.ti,ab,ot.

18. 16 or 17

19.8 and 14

20. 19 not (15 not (15 and 18))

21. case reports.pt.

22. letter.pt.

23. 21 or 22

24. 20 not 23

\section{Embase}

1. exp asthma/

2. asthma.ti,ab,ot.

3. (Acute adj4 asthma).ti,ab,ot.

4. exacerbat*.ti,ab,ot.

5. 1 or 2

6. 4 and 5

7. (attack adj3 asthma).ti,ab,ot.

8.3 or 6 or 7

9. (severe adj3 asthma).ti,ab,ot.

10. Validat\$.tw. or Predict\$.ti. or Rule\$.tw.

11. ((Predict\$ and (Outcome\$ or Risk\$ or Model\$)) or ((History or Variable\$ or Criteria or Scor\$ or Characteristic $\$$ or Finding\$ or Factor\$) and (Predict\$ or Model\$ or Decision\$ or Identif\$ or Prognos\$))).tw. 12. (Decision\$.tw. and ((Model\$ or Clinical\$).tw. or statistical model/)) or (Prognostic and (History or Variable\$ or Criteria or Scor\$ or Characteristic\$ or Finding\$ or Factor\$ or Model\$)).tw.

13. exp receiver operating characteristic/

14. ("Stratification" or "Discrimination" or "Discriminate" or "c-statistic" or "c statistic" or "Area under the curve" or "AUC" or "Calibration" or "Indices" or "Algorithm" or "Multivariable").tw.

15.11 or 12 or 13 or 14

16. 8 and 15

17. 10 or 11 or 12

18. 8 and 17

19. child/

20. child*.ti,ab,ot.

21. pediatrics.mp. or exp pediatrics/

22. child*.mp.

23. 19 or 21 or 22

24. adult/

25. adult.ti,ab,ot.

26. 24 or 25

27. 18 not (23 not (23 and 26))

28. 18 and 23

29. 16 not (23 not (23 and 26))

30. CONFERENCE ABSTRACT.pt.

31. case report/

32. letter/

33. editorial/

34.30 or 31 or 32 or 33

35. 29 not 34 


\section{Table E1}

\begin{tabular}{|l|l|l|}
\hline & Accurate & U-BIOPRED \\
\hline & $\mathrm{N}=611$ & $\mathrm{n}=317$ \\
\hline Age (yrs, SD; range) & $39.4,9.1 ; 17-55$ & $52.6,13.2 ; 19-78$ \\
\hline Sex (\% female) & 68.4 & 60.1 \\
\hline Body Mass Index (kg/m2, SD; range) & $26.4,5.4 ; 13.0-56.8$ & $8.9,5.9 ; 17.8-49.0$ \\
\hline Current smokers (\%) & 14.4 & 11.1 \\
\hline & & \\
\hline ACQ-5 (baseline mean score, SD; range) & $1.0,0,9 ; 0-5.4$ & $2.2,1.2 ; 0-5.8$ \\
\hline Severe exacerbation prevous year (\%) & 11.6 & 66.5 \\
\hline Ever hospitalized for asthma (\%) & 12.3 & 66.3 \\
\hline FEV1 (mean \% predicted, SD; range) & $91.3,15.4 ; 36.8-137.0$ & $66.3,21.0 ; 18.4-119.6$ \\
\hline FeNO (ppb, SD; range) & $23.8,23.9 ; 5-228$ & $36.3,32.1 ; 2-191$ \\
\hline
\end{tabular}




\section{Table E2}

\section{overview of identified reports on prediction models for exacerbations in adult patients with asthma}

\begin{tabular}{|c|c|c|c|c|c|c|}
\hline Study & Setting & Population & Purpose, outcome & Model development & Performance & Predictors \\
\hline $\begin{array}{l}\text { Identifying patients at risk } \\
\text { for severe exacerbations of } \\
\text { asthma: development and } \\
\text { external validation of a } \\
\text { multivariable prediction } \\
\text { model } \\
\text { Loymans et al. } \\
\text { Thorax 2016; 47: 422-8 }\end{array}$ & $\begin{array}{l}\text { Asthma control } \\
\text { cost-utility } \\
\text { randomized trial } \\
\text { evaluation } \\
\text { (ACCURATE) } \\
\text { pragmatic trial } \\
\text { multiple general } \\
\text { practices in the } \\
\text { Netherlands } \\
\text { primary care } \\
\text { 2009-2012 } \\
\text { prospective }\end{array}$ & $\begin{array}{l}611 \text { patients } \\
\text { mean age (SD), [range] at inclusion: } \\
39.4(9.5),[18-50] \text { years } \\
\text { (\% female): } \\
68.7 \\
\text { inclusion criteria: } \\
\text { doctor-diagnosed asthma according to the } \\
\text { Dutch national guidelines, a prescription for } \\
\text { ICSs for at least } 3 \text { months in the previous } \\
\text { year, and asthma being managed in primary } \\
\text { care. }\end{array}$ & $\begin{array}{l}\text { purpose: } \\
\text { model development and external validation } \\
\text { outcome: } \\
\text { patients with one or more hospitalizations or ED } \\
\text { visits or systemic corticosteroids, according to } \\
\text { ATS/ERS recommendations } \\
\text { patients with events: } \\
80 \\
\text { prediction horizon: } \\
12 \text { months }\end{array}$ & $\begin{array}{l}\text { number of candidate predictors: } \\
15 \\
\text { statistical analysis: } \\
\text { binomial logistic regression } \\
\text { number of final predictors: } \\
5 / 6 / 7 \\
\text { model presentation: } \\
\text { coefficients with intercept, score } \\
\text { system }\end{array}$ & $\begin{array}{l}\text { discrimination: } \\
0.77 / 0.79 / 0.90 \\
\\
\text { calibration: } \\
\text { calibration plots and HL-test } \\
\\
\text { validation: } \\
0.72 / 0.72 / 0.72\end{array}$ & $\begin{array}{l}\text { History model: } \\
\text { ACQ-5 score, } \\
\text { current smoking, } \\
\text { chronic sinusitis, } \\
\text { previous hospital admission } \\
\text { for asthma and } \\
\geq 1 \text { severe exacerbation in the } \\
\text { previous year } \\
\text { Spirometry model: } \\
\text { + FEV1 predicted pre } \\
\text { bronchodilation } \\
\text { FeNO model: } \\
\text { + FeNO corrected for smoking }\end{array}$ \\
\hline $\begin{array}{l}\text { Development and } \\
\text { validation of a novel risk } \\
\text { score for asthma } \\
\text { exacerbations: The risk } \\
\text { score for exacerbations } \\
\text { Bateman et al. } \\
\text { J Allergy Clin Immunol } \\
\text { 2015; 104: } 945-56\end{array}$ & $\begin{array}{l}\text { Three large trials } \\
\text { comparing } \\
\text { SMART vs } \\
\text { ICS/LABA therapy } \\
708 \text { centres } \\
\text { worldwide } \\
\text { secondary care } \\
2003-2006 \\
\text { retrospective }\end{array}$ & $\begin{array}{l}7,446 \text { patients } \\
\text { mean age (SD), [range] at inclusion } \\
39.5(16.8),[12-89] \\
\text { sex (\% female): } \\
59 \\
\text { inclusion criteria: } \\
\text { uncontrolled asthma patients receiving } \\
\text { GINA treatment steps } 3 \text { or } 4 \text { with a pre- } \\
\text { bronchodilator FEV1 of } 50 \% \text { or greater of } \\
\text { predicted normal value and } 1 \text { or more } \\
\text { exacerbations in the previous year. }\end{array}$ & $\begin{array}{l}\text { purpose: } \\
\text { model development } \\
\text { outcome: } \\
\text { asthma worsening requiring } 3 \text { or more days of } \\
\text { oral corticosteroids, emergency department } \\
\text { treatment, hospitalization, or both } \\
\text { patients with events: } \\
1197 \text { (estimated*) } \\
\text { prediction horizon: } \\
6 \text { months }\end{array}$ & $\begin{array}{l}\text { number of candidate predictors: } \\
16 \\
\text { statistical analysis: } \\
\text { backward stepwise Cox regression } \\
\text { number of final predictors: } \\
5 \\
\text { model presentation: } \\
\text { risk score }\end{array}$ & $\begin{array}{l}\text { discrimination: } \\
\text { not reported } \\
\text { calibration: } \\
\text { calibration plots } \\
\\
\text { validation: } \\
\text { internal; split sample }\end{array}$ & $\begin{array}{l}\text { Body mass index } \\
\text { ACQ-5 } \\
\text { FEV1\%pred-postBD } \\
\text { Reliever use } \\
\text { GINA treatment step }\end{array}$ \\
\hline
\end{tabular}




\begin{tabular}{|c|c|c|c|c|c|c|}
\hline $\begin{array}{l}\text { Severity of Asthma Score } \\
\text { Predicts Clinical } \\
\text { Outcomes in Patients With } \\
\text { Moderate } \\
\text { to Severe Persistent Astma } \\
\text { Eisner et al. } \\
\text { Chest 2012; 141: 58-65 }\end{array}$ & $\begin{array}{l}\begin{array}{l}\text { EXCELS; } \\
\text { observational study } \\
\text { (non-Xolair cohort) }\end{array} \\
\text { multiple locations } \\
\text { in USA } \\
\text { mixed care } \\
2004-2006 \\
\text { prospective }\end{array}$ & $\begin{array}{l}2,878 \text { patients } \\
\text { mean age (SD) at inclusion } \\
47 \text { (17) } \\
\text { sex (\% female): } \\
66 \\
\text { inclusion criteria: } \\
\geq 12 \text { years old, physician diagnosis of } \\
\text { moderate to severe persistent asthma, and a } \\
\text { history of a positive response to allergy skin } \\
\text { testing or in vitro serum-specific IgE } \\
\text { reactivity to aeroallergens Patients were } \\
\text { excluded when they had experienced an } \\
\text { asthma exacerbation } 2 \text { weeks before } \\
\text { screening, or an acute flare-up of symptoms, } \\
\text { or a hospitalization within } 2 \text { months of } \\
\text { screening. }\end{array}$ & $\begin{array}{l}\text { purpose: } \\
\text { model external validation } \\
\text { outcome: } \\
\text { 1) systemic corticosteroid bursts } \\
\text { 2) ED visits } \\
\text { 3) SAEs reported as exacerbations } \\
\text { 4) SAEs leading to hospitalizations } \\
\text { 5) unscheduled office visits } \\
\text { events: } \\
\text { not reported } \\
\text { prediction horizon: } \\
12 \text { months }\end{array}$ & $\begin{array}{l}\text { number of candidate predictors: } \\
4 \\
\text { statistical analysis: } \\
\text { logistic regression and CART } \\
\text { modelling } \\
\\
\text { number of final predictors: } \\
13 \text {-item SOA score; added with } \\
\text { ACT and/or FEV1\% pending the } \\
\text { outcome predicted } \\
\text { model presentation: } \\
\text { coefficients with intercept }\end{array}$ & $\begin{array}{l}\text { discrimination: } \\
\text { AUROC } \\
\text { 1) } 0.690 \\
\text { 2) } 0.751 \\
\text { 3) } 0.783 \\
\text { 4) } 0.689 \\
\text { 5) } 0.684 \\
\text { calibration: } \\
\text { not reported } \\
\text { validation: } \\
\text { external validation study }\end{array}$ & $\begin{array}{l}\text { SOA: } \\
\text { Symptoms past } 2 \text { wks } \\
\text { Systemic corticosteroids } \\
\text {-ever used } \\
\text {-past year } \\
-3 \text { mo past } 2 \text { yr } \\
\text { Other asthma medications } \\
\text {-Beta-agonists } \\
\text {-ICS } \\
\text {-Cromolyn/nedocromil } \\
\text {-Anticholinergics } \\
\text {-Theophyllin/LTRA } \\
\text {-antihistaminics/nasal } \\
\text {-nebulizer } \\
\text { Ever hospitalized } \\
\text { Ever intubated } \\
\text { Asthma Control Test } \\
\text { FEV1\%predicted }\end{array}$ \\
\hline $\begin{array}{l}\text { The Strategy for } \\
\text { Predicting Future } \\
\text { Exacerbation of Asthma } \\
\text { Using a } \\
\text { Combination of the } \\
\text { Asthma Control Test and } \\
\text { Lung Function Test } \\
\text { Sato et al. } \\
\text { J. Asthma 2009; 46: 677- } \\
82\end{array}$ & $\begin{array}{l}\text { observational } \\
\text { retrospective cohort } \\
\text { single centre Japan } \\
\text { secondary care } \\
\text { time not reported } \\
\text { retrospective }\end{array}$ & $\begin{array}{l}78 \text { patients } \\
\text { mean age at inclusion } \\
62.3 \\
\text { (\% female): } \\
57.7 \\
\text { inclusion criteria: } \\
\text { clinically stable on ICS for at least } 3 \text { months } \\
\text { without exacerbations (including } \\
\text { hospitalization, ED visits, or treatment with } \\
\text { systemic corticosteroids), receiving mainly } \\
\text { ICS without any change in their treatment } \\
\text { regimen. }\end{array}$ & $\begin{array}{l}\text { purpose: } \\
\text { model development } \\
\text { outcome: } \\
2 \text { or more consecutive days of a PEFR } \leq 70 \% \text { of } \\
\text { baseline morning PEFR, a filled prescription for } \\
\text { oral corticosteroids, an ED visit, or } \\
\text { hospitalization due to asthma } \\
\text { patients with events: } \\
16 \text { ( } 21 \%) \\
\text { prediction horizon: } \\
12 \text { months }\end{array}$ & $\begin{array}{l}\text { number of candidate predictors: } \\
\text { unclear, at least } 4 \\
\text { statistical analysis: } \\
\text { CART modelling } \\
\text { number of final predictors: } \\
3 \\
\text { model presentation: } \\
\text { classification tree }\end{array}$ & $\begin{array}{l}\text { discrimination: } \\
\text { AUROC } \\
0.613 / 0.678 / 0.625 \\
\\
\text { calibration: } \\
\text { not reported } \\
\\
\text { validation: } \\
\text { not reported }\end{array}$ & $\begin{array}{l}\text { ACT } \\
\text { FEV1 \%predicted } \\
\text { FeNO }\end{array}$ \\
\hline $\begin{array}{l}\text { Assessing Future Need for } \\
\text { Acute Care } \\
\text { in Adult Asthmatics } \\
\text { The Profile of Asthma } \\
\text { Risk Study: A Prospective } \\
\text { Health Maintenance } \\
\text { Organization-Based Study } \\
\text { Osborne et al. } \\
\text { Chest 2007; 132: 1151-61 }\end{array}$ & $\begin{array}{l}\text { administrative } \\
\text { database } \\
\text { (Kaiser } \\
\text { Permanente } \\
\text { managed care } \\
\text { organization) } \\
\text { multiple locations } \\
\text { in USA } \\
\text { mixed care } \\
\text { time not reported } \\
\text { prospective }\end{array}$ & $\begin{array}{l}554 \text { patients } \\
\text { mean age (SD), [range] at inclusion } \\
36.9 \text { (9.3), [18-55] } \\
\text { (\% female): } \\
61 \\
\text { inclusion criteria: } \\
\text { hospitalized for asthma the } 2 \text { years before } \\
\text { recruitment or have at least } 2 \text { dispensings of } \\
\text { asthma medication in the year before } \\
\text { recruitment. On inclusion a physician } \\
\text { diagnosis of asthma and reporting asthma } \\
\text { symptoms. Individuals taking daily oral } \\
\text { steroids were excluded. }\end{array}$ & $\begin{array}{l}\text { purpose: } \\
\text { model development } \\
\text { outcome: } \\
\text { emergency department visits, hospital-based } \\
\text { "urgency care clinic" visits, or hospitalizations } \\
\text { for asthma } \\
\text { events: } \\
173 \\
\text { prediction horizon: } \\
30 \text { months }\end{array}$ & $\begin{array}{l}\text { number of candidate predictors: } \\
\text { not reported } \\
\text { statistical analysis: } \\
\text { Poisson regression backward } \\
\text { stepwise } \\
\text { number of final predictors: } \\
12 / 11 / 10 \\
\text { model presentation: } \\
\text { score system; } 3 \text { models, model } \\
\text { based on questionnaire, extended } \\
\text { with spirometry and subsequently } \\
\text { with skin prick test data }\end{array}$ & $\begin{array}{l}\text { discrimination: } \\
\text { not reported } \\
\text { calibration: } \\
\text { not reported } \\
\\
\text { validation: } \\
\text { split sample }\end{array}$ & $\begin{array}{l}\text { A: age, } \\
\text { education, } \\
\text { double pane windows, caffeine } \\
\text { consumption, sensitive to } \\
\text { indoor allergens, } \\
\text { owns cat/dog, } \\
\text { night time symptoms, perennial } \\
\text { asthma, } \\
\text { impact on school/work, health } \\
\text { care utilization prior year, } \\
\text { ER visit ever, } \\
\text { hospitalization, } \\
\text { B: + FEV1 } \\
\text { C: + skin prick test positive for } \\
\text { cat/dog }\end{array}$ \\
\hline
\end{tabular}




\begin{tabular}{|c|c|c|c|c|c|c|}
\hline $\begin{array}{l}\text { TENOR risk score } \\
\text { predicts healthcare in } \\
\text { adults with severe or } \\
\text { difficult-to-treat asthma } \\
\text { Miller et al. } \\
\text { Eur Respir J 2006; } 28 \text { : } \\
1145-55\end{array}$ & $\begin{array}{l}\text { The Epidemiology } \\
\text { and Natural } \\
\text { History of Asthma: } \\
\text { Outcomes and } \\
\text { Treatment } \\
\text { Regimens } \\
\text { (TENOR) study } \\
\text { multiple locations } \\
\text { in USA } \\
\text { secondary care } \\
\text { 2001-2004 } \\
\text { prospective }\end{array}$ & $\begin{array}{l}2,821 \text { patients } \\
\text { mean age (SD) at inclusion } \\
49.7 \text { (14.7) } \\
\text { sex (\% female): } \\
71.6 \\
\text { inclusion criteria: } \\
\text { clinician-assessed severe or difficult-to-treat } \\
\text { asthma: e.g. received care for at least } 1 \text { yr, } \\
\text { had high healthcare use ( } \geq 2 \text { unscheduled } \\
\text { care visits or oral corticosteroid bursts) } \\
\text { and/or high medication use (required } \geq 3 \\
\text { controller medications, need for high doses } \\
\text { of inhaled corticosteroids or oral } \\
\text { prednisone) in the previous } 12 \text { months }\end{array}$ & $\begin{array}{l}\text { purpose: } \\
\text { model development and validation } \\
\text { outcome: } \\
\text { ED visit or overnight hospitalisation } \\
\text { patients with events: } \\
239(8.5 \%) \\
\text { prediction horizon: } \\
6 \text { months }\end{array}$ & $\begin{array}{l}\text { number of candidate predictors: } \\
140 \\
\text { statistical analysis: } \\
\text { forward stepwise logistic } \\
\text { regression } \\
\text { number of final predictors: } \\
12 / 14 \text { / } 16 \\
\text { model presentation: } \\
\text { score system; } 3 \text { models, original } \\
\text { model extended with patient } \\
\text { reported outcomes and } \\
\text { subsequently with healthcare use }\end{array}$ & $\begin{array}{l}\text { discrimination: } \\
\text { c-statistic: } \\
0.783 / 0.798 \text { / 0.816; } \\
\text { internal validation: } \\
0.769 / 0.790 \text { / } 0.810 \\
\\
\text { calibration: } \\
\text { not reported } \\
\\
\text { validation: } \\
\text { internal; split sample (time) }\end{array}$ & $\begin{array}{l}\text { 1) age, } \\
\text { sex, } \\
\text { race, } \\
\text { BMI, } \\
\text { lung function, } \\
\text { Previous pneumonia, current } \\
\text { diabetes, } \\
\text { current cataract, } \\
\text { ever intubated, } \\
\text { steroid burst } 3 \text { mo, nebuliser, } \\
\text { syst corticosteroids } \\
\text { 2) +health compared to others } \\
\text { and night time awakening } \\
\text { 3) +previous ED visits and } \\
\text { scheduled office visits }\end{array}$ \\
\hline $\begin{array}{l}\text { Using an Asthma Control } \\
\text { Questionnaire } \\
\text { and Administrative Data } \\
\text { To Predict } \\
\text { Health-Care Utilization } \\
\text { Peters et al. } \\
\text { Chest 2006; 129: 918-24 }\end{array}$ & $\begin{array}{l}\text { administrative } \\
\text { database } \\
\text { (Kaiser } \\
\text { Permanente } \\
\text { managed care } \\
\text { organization) } \\
\text { multiple locations } \\
\text { in USA } \\
\text { mixed care } \\
1997-1998 \\
\text { retrospective }\end{array}$ & $\begin{array}{l}4,788 \text { patients } \\
\text { mean age [range] at inclusion } \\
52[17-93] \\
\text { (\% female): } \\
68 \\
\text { inclusion criteria: } \\
\text { Surveyed had received } \geq 2 \text { doses of asthma } \\
\text { medications in the previous year and/or had } \\
\text { a hospital or ED visit for asthma in } 1994, \\
\text { 1995, or } 1996 . \text { Eligible patients reported } \\
\text { having a doctor diagnosis of asthma and } \\
\text { were currently on asthma medications. }\end{array}$ & $\begin{array}{l}\text { purpose: } \\
\text { model development } \\
\text { outcome: } \\
\text { acute asthma care events: hospitalizations or ED } \\
\text { visits or other acute care contacts. } \\
\text { events: } \\
10.4 \% \\
\text { prediction horizon: } \\
12 \text { months }\end{array}$ & $\begin{array}{l}\text { number of candidate predictors: } \\
\text { not reported } \\
\text { statistical analysis: } \\
\text { CART modelling } \\
\text { number of final predictors: } \\
2 / 4 \\
\begin{array}{l}\text { model presentation: } \\
\text { classification tree }\end{array}\end{array}$ & $\begin{array}{l}\text { discrimination: } \\
\text { not reported } \\
\text { calibration: } \\
\text { not reported } \\
\\
\text { validation: } \\
\text { not reported }\end{array}$ & $\begin{array}{l}\text { 1) ATAQ } \\
\text { age } \\
\text { 2) Prior ED } \\
\text { Prior Urgent Care } \\
\text { ATAQ } \\
\text { age }\end{array}$ \\
\hline $\begin{array}{l}\text { Predicting patient-reported } \\
\text { asthma outcomes for } \\
\text { adults in managed care. } \\
\text { Yurk et al. } \\
\text { Am J Manag Care 2004; } \\
\text { 10: } 321-8\end{array}$ & $\begin{array}{l}\text { administrative } \\
\text { database } \\
16 \text { Managed Care } \\
\text { Organizations in } \\
\text { USA } \\
\text { mixed care } \\
1993 \\
\text { prospective }\end{array}$ & $\begin{array}{l}4,888 \text { patients } \\
\text { mean age at inclusion } \\
45 \\
\text { (\% female): } \\
69 \\
\text { inclusion criteria: } \\
2 \text { or more asthma encounters (visits or } \\
\text { hospitalizations ICD code } 493 . X) \text { during the } \\
\text { previous } 2 \text { years; age } 18 \text { years or older and } \\
\text { enrollment in the managed care organization } \\
\text { at the time of sampling }\end{array}$ & $\begin{array}{l}\text { purpose: } \\
\text { model development and validation } \\
\text { outcome: } \\
\text { A composite measure combining } \\
\text { hospitalization, ED use, and lost activity days } \\
\text { (other reported models predicting } \\
\text { hospitalizations, ED-visits, lost activity days and } \\
\text { severe symptoms reported merely odds rations } \\
\text { and therefor did not fulfil inclusion criteria) } \\
\text { events: } \\
\text { not reported } \\
\text { prediction horizon: } \\
12 \text { months }\end{array}$ & $\begin{array}{l}\text { number of candidate predictors: } \\
\text { not reported } \\
\text { statistical analysis: } \\
\text { logistic regression } \\
\text { number of final predictors: } \\
14 \\
\text { model presentation: } \\
\text { score system }\end{array}$ & $\begin{array}{l}\text { discrimination: } \\
\text { c-statistic: } \\
0.783 \\
\\
\text { calibration: } \\
\text { not reported } \\
\\
\text { validation: } \\
\text { not reported }\end{array}$ & $\begin{array}{l}\text { Age, gender, race, education, } \\
\text { history of myocardial } \\
\text { infarction, history of } \\
\text { emphysema/chronic bronchitis, } \\
\text { history of gastro-intestinal } \\
\text { bleeding, ED visit for asthma } \\
\text { past } 12 \text { months, physician } \\
\text { outpatient visit past } 6 \text { months, } \\
\text { limited activities, asthma } \\
\text { attacks, symptoms, self-rated } \\
\text { health, methylxanthione use. }\end{array}$ \\
\hline
\end{tabular}




\begin{tabular}{|c|c|c|c|c|c|c|}
\hline $\begin{array}{l}\text { Risk Factors for Asthma } \\
\text { Hospitalizations } \\
\text { in a Managed Care } \\
\text { Organization: } \\
\text { Development of a Clinical } \\
\text { Prediction Rule } \\
\text { Schatz et al. } \\
\text { Am J Manag Care 2003; } \\
\text { 9:538-47 }\end{array}$ & $\begin{array}{l}\text { administrative } \\
\text { database } \\
\text { (Kaiser } \\
\text { Permanente } \\
\text { managed care } \\
\text { organization) } \\
\text { multiple locations } \\
\text { in USA } \\
\text { mixed care } \\
1998 \text { - } 1999 \\
\text { retrospective }\end{array}$ & $\begin{array}{l}6,904 \text { patients (adults) } \\
\text { mean age (SD) at inclusion } \\
\text { mean } 43.7 \text { (12.3) } \\
\text { sex (\% female): } \\
63.5 \\
\text { inclusion criteria: } \\
\text { one or more of the following: } \\
\text { 1) discharge diagnosis of asthma in the } \\
\text { hospitalization database (ICD-9 code: } \\
\text { 493.xx), 2) } \geq 2 \text { asthma-related medication } \\
\text { dispensings in a 1-year period in the } \\
\text { prescription database, 3) ED or regular } \\
\text { clinic asthma-related visit in the diagnosis } \\
\text { and procedures database. }\end{array}$ & $\begin{array}{l}\text { purpose: } \\
\text { model development and validation } \\
\text { outcome: } \\
\text { hospitalization } \\
\text { patients with events: } \\
83(1.2 \%) \\
\text { prediction horizon: } \\
12 \text { months }\end{array}$ & $\begin{array}{l}\text { number of candidate predictors: } \\
12 \\
\text { statistical analysis: } \\
\text { backward stepwise logistic } \\
\text { regression } \\
\text { number of final predictors: } \\
3 \\
\text { model presentation: } \\
\text { coefficients with intercept }\end{array}$ & $\begin{array}{l}\text { discrimination: } \\
\text { c-statistic: } 0.712 \\
\text { calibration: } \\
\text { Not reported } \\
\text { validation: } \\
\text { internal; bootstrap \& jackknifed } \\
\text { estimates }\end{array}$ & $\begin{array}{l}\text { prior hospitalizations, } \\
\text { oral steroids, } \\
\text { income }\end{array}$ \\
\hline $\begin{array}{l}\text { Computer-Based Models } \\
\text { to Identify High-Risk } \\
\text { Adults with Asthma: Is the } \\
\text { Glass Half Empty or Half } \\
\text { Full? } \\
\text { Lieu et al. } \\
\text { J. Asthma 1999; 36: } 359- \\
70\end{array}$ & $\begin{array}{l}\text { administrative } \\
\text { database } \\
\text { (Kaiser } \\
\text { Permanente } \\
\text { managed care } \\
\text { organization) } \\
32 \text { clinics } \\
\text { In USA } \\
\text { mixed care } \\
1995-1996 \\
\text { retrospective }\end{array}$ & $\begin{array}{l}\text { 7,141 patients } \\
\text { mean age (SD), [range] at inclusion } \\
43.8(16[18-101]) \\
\text { sex (\% female): } \\
63 \\
\text { inclusion criteria: } \\
\text { hospitalization, ED visit, or outpatient clinic } \\
\text { visit with an ICD-9-code of } 493 \text {.XX during } \\
\text { the } 2 \text { years prior to the start of follow-up. In } \\
\text { addition, any adult aged } 18-44 \text { years who } \\
\text { used asthma medications during that time } \\
\text { period was included. Adults aged } 45 \text { and } \\
\text { older using asthma medications were only } \\
\text { included when they had an } \\
\text { ICD-9-coded diagnosis of asthma. }\end{array}$ & $\begin{array}{l}\text { purpose: } \\
\text { model development and validation } \\
\text { outcome: } \\
\text { asthma-related hospitalization or ED visit during } \\
\text { the follow-up year } \\
\text { events: } \\
493(6.9 \%) \\
\text { prediction horizon: } \\
12 \text { months }\end{array}$ & $\begin{array}{l}\text { number of candidate predictors: } \\
8 \\
\text { statistical analysis: } \\
\text { CART modelling } \\
\text { number of final predictors: } \\
4 / 3 \\
\text { model presentation: } \\
\text { classification tree }\end{array}$ & $\begin{array}{l}\text { discrimination: } \\
\text { Not applicable } \\
\text { calibration: } \\
\text { Not applicable } \\
\text { validation: } \\
\text { internal; split sample and mixed } \\
\text { test }\end{array}$ & $\begin{array}{l}\text { Tree A: } \\
5 \text { asthma medications } \\
\text { previous } 6 \text { months, } \\
\geq 2 \text { oral steroid courses } \\
\text { previous } 12 \text { months, } \\
\text { ICS/LABA ratio }<1.4 \text {, } \\
\text { ED visit prior } 12 \text { mo } \\
\\
\text { Tree B: } \\
5 \text { asthma medications } \\
\text { previous } 6 \text { months } \\
\geq 2 \text { oral steroid courses } \\
\text { previous } 12 \text { months, } \\
\text { ED visit prior } 12 \text { months }\end{array}$ \\
\hline $\begin{array}{l}\text { A New Index of } \\
\text { Prognostic Severity for } \\
\text { Chronic Asthma } \\
\text { Ellman et al } \\
\text { Chest 1997; 112: 582-90 }\end{array}$ & $\begin{array}{l}\text { crossover trial of } \\
\text { regular vs } \\
\text { as-needed } \\
\text { inhaled B-agonist } \\
\text { therapy } \\
\text { Dunedin (New } \\
\text { Zealand) } \\
\text { Mixed care } \\
1988-1989 \\
\text { retrospective }\end{array}$ & $\begin{array}{l}70 \text { patients (138 periods of follow-up) } \\
\text { mean age (SD), [range] at inclusion } \\
\text { median } 38[15-64] \\
\text { (\% female): } \\
57 \% \\
\text { inclusion criteria: } \\
\text { the presence of asthma for }>1 \text { year with a } \\
>20 \% \text { rise in FEV1 after inhaled } \\
\text { bronchodilator on two or more occasions } \\
\text { and airway hyper- responsiveness to } \\
\text { methacholine }\end{array}$ & $\begin{array}{l}\text { purpose: } \\
\text { model development } \\
\text { outcome: } \\
\text { asthma deterioration within } 20 \text { weeks, defined as } \\
\text { either a marked decline in FEV1 } \geq 1 \mathrm{~L} \text { or } \geq 30 \% \\
\text { from baseline) or initiation of systemic } \\
\text { corticosteroid therapy for asthma exacerbation. } \\
\text { patients with events: } \\
38 \\
\text { prediction horizon: } \\
20 \text { weeks }\end{array}$ & $\begin{array}{l}\text { number of candidate predictors: } \\
13 \\
\text { statistical analysis: } \\
\text { repeated cross-stratification; } \\
\text { forward stepwise logistic } \\
\text { regression } \\
\text { number of final predictors: } \\
3 \\
\text { model presentation: } \\
\begin{array}{l}\text { Prognostic index (cross } \\
\text { stratification table) }\end{array}\end{array}$ & $\begin{array}{l}\text { discrimination: } \\
\text { not reported } \\
\text { calibration: } \\
\text { not reported } \\
\text { validation: } \\
\text { internal; split sample }\end{array}$ & $\begin{array}{l}\text { age } \\
\text { hospitalisation } \\
\text { awakening }\end{array}$ \\
\hline
\end{tabular}




\begin{tabular}{|c|c|c|c|c|c|c|}
\hline $\begin{array}{l}\text { The Use of Aministrative } \\
\text { Data to Risk-Stratify } \\
\text { Asthmatic Patients } \\
\text { Grana et al. } \\
\text { Am J Med Qual 1997; 12: } \\
\text { 113-9 }\end{array}$ & \begin{tabular}{|l} 
administrative \\
database \\
(U.S. Healthcare) \\
Eastern USA \\
$1993-1995$ \\
retrospective
\end{tabular} & $\begin{array}{l}54,573 \text { patients } \\
\text { mean age (SD), [range] at inclusion } \\
\text { not reported } \\
\text { sex (\% female): } \\
\text { not reported } \\
\text { inclusion criteria: } \\
\text { diagnosis, pharmacy NDC or procedure } \\
\text { code that was asthma specific. Pharmacy } \\
\text { NDC codes had to occur at least twice. }\end{array}$ & $\begin{array}{l}\text { purpose: } \\
\text { model development and validation } \\
\text { outcome: } \\
\text { hospitalisation } \\
\text { events: } \\
1000 \\
\\
\text { prediction horizon: } \\
1 \text { year }\end{array}$ & $\begin{array}{l}\text { number of candidate predictors: } \\
49 \\
\text { statistical analysis: } \\
\text { logistic regression } \\
\text { number of final predictors: } \\
34 \\
\text { model presentation: } \\
\text { coefficients with intercept }\end{array}$ & $\begin{array}{l}\text { discrimination: } \\
\text { not reported } \\
\text { calibration: } \\
\text { Table with agreement of deciles } \\
\text { with expected and observed } \\
\text { events } \\
\text { validation: } \\
\text { Internal; cross validation (time) }\end{array}$ & $\begin{array}{l}\text { Sex, age, medicaid subscriber, } \\
\text { NewYork, COPD, ischemic } \\
\text { heart disease, pharmacy plan, } \\
\text { medication level 1-5, } \\
\text { hospitalisations, ED visits, } \\
\text { primary care visits, enrolment } \\
\text { duration (several time spans). }\end{array}$ \\
\hline
\end{tabular}


Table E3 results of external validation: calibration-in-the-large and slope

\begin{tabular}{|c|c|c|c|c|c|c|c|c|c|c|}
\hline \multirow{3}{*}{$1^{\text {st }}$ auhor / year } & \multirow{3}{*}{ Model } & & \multicolumn{4}{|c|}{ ACCURATE } & \multicolumn{4}{|c|}{ U-BIOPRED } \\
\hline & & & \multicolumn{2}{|c|}{ Author defined outcome* } & \multicolumn{2}{|c|}{ Standard (ATS/ERS) outcome } & \multicolumn{2}{|c|}{ Author defined outcome* } & \multicolumn{2}{|c|}{ Standard (ATS/ERS) outcome } \\
\hline & & & $\mathrm{CIL}^{\dagger}(\mathrm{SE})$ & slope (SE) & $\mathrm{CIL}^{\dagger}(\mathrm{SE})$ & slope (SE) & $\mathrm{CIL}^{\dagger}(\mathrm{SE})$ & slope (SE) & $\mathrm{CIL}^{\dagger}(\mathrm{SE})$ & slope (SE) \\
\hline \multirow[t]{3}{*}{ Loymans 2016} & History & $\begin{array}{l}\text { ATS/ERS severe } \\
\text { exacerbations }\end{array}$ & - & - & - & - & - & - & $1.51(0.15)$ & $0.27(0.05)$ \\
\hline & + Spiro & $\begin{array}{l}\text { ATS/ERS severe } \\
\text { exacerbations }\end{array}$ & - & - & - & - & - & - & $-0.66(0.16)$ & $0.27((0.05)$ \\
\hline & $+\mathrm{FeNO}$ & $\begin{array}{l}\text { ATS/ERS severe } \\
\text { exacerbations }\end{array}$ & - & - & - & - & - & - & $-0.68(0.16)$ & $0.26(0.05)$ \\
\hline Bateman 2015 & & $\begin{array}{l}\text { ATS/ERS severe } \\
\text { exacerbations }\end{array}$ & - & - & - & - & - & - & - & - \\
\hline \multirow[t]{4}{*}{ Eisner 2012} & OCS & OCS & $-1.14(0.25)$ & $1.83(0.54)$ & $-0.97(0.12)$ & $2.19(0.29)$ & $-1.10(0.13)$ & $0.65(0.24)$ & $0.23(0.12)$ & $1.06(0.22)$ \\
\hline & ED & ED & $-1.42(0.38)$ & $1.83(0.53)$ & $1.23(0.12)$ & $1.54(0.20)$ & $-1.31(0.25)$ & $0.87(0.35)$ & $2.00(0.12)$ & $0.64(0.14)$ \\
\hline & HOS & HOS & $-0.70(0.41)$ & $2.10(0.81)$ & $2.05(0.12)$ & $2.23(0.30)$ & $0.94(0.18)$ & $0.93(0.39)$ & $3.33(0.12)$ & $1.14(0.24)$ \\
\hline & UV & UV & $-2.41(0.23)$ & $2.15(0.48)$ & $-0.84(0.12)$ & $2.25(0.29)$ & $-2.03(0.18)$ & $0.23(0.32)$ & $0.38(0.12)$ & $1.04(0.22)$ \\
\hline Sato 2009 & & & - & - & $-1.09(0.16)$ & $0.10(0.05)$ & - & - & $0.47(0.14)$ & $0.00(0.03)$ \\
\hline \multirow[t]{3}{*}{ Osborne 2007} & PAR-A & $\mathrm{ED} / \mathrm{HOS} / \mathrm{UV}$ & - & - & - & - & - & - & - & - \\
\hline & PAR-B & $\mathrm{ED} / \mathrm{HOS} / \mathrm{UV}$ & - & - & - & - & - & - & - & - \\
\hline & PAR-C & $\mathrm{ED} / \mathrm{HOS} / \mathrm{UV}$ & - & - & - & - & - & - & - & - \\
\hline \multirow[t]{3}{*}{ Miller 2006} & TENOR & ED/HOS & $-1.21(0.37)$ & $0.77(0.26)$ & $1.52(0.13)$ & $0.31(0.12)$ & $0.20(0.21)$ & $0.15(0.16)$ & $3.30(0.13)$ & $0.32(0.10)$ \\
\hline & + PRO & ED/HOS & - & - & - & - & - & - & - & - \\
\hline & $+\mathrm{HCU}$ & ED/HOS & - & - & - & - & - & - & - & - \\
\hline \multirow[t]{2}{*}{ Peters 2006} & 1 & $\mathrm{ED} / \mathrm{HOS} / \mathrm{UV}$ & $-1.37(0.05)$ & $0.99(0.29)$ & $-0.05(0.12)$ & $0.73(0.18)$ & $0.63(0.13)$ & $0.57(0.22)$ & $2.00(0.12)$ & $0.20(0.20)$ \\
\hline & 2 & $\mathrm{ED} / \mathrm{HOS} / \mathrm{UV}$ & $-1.26(0.21)$ & $1.02(0.25)$ & $0.07(0.13)$ & $0.31(0.16)$ & $0.82(0,14)$ & $0.25(0.13)$ & $2.33(0.12)$ & $0.20(0.12)$ \\
\hline Schatz 2003 & & HOS & $-1.57(0.41)$ & $0.75(0.47)$ & $1.27(0.13)$ & $0.89(0.16)$ & $-0.24(0.19)$ & $0.62(0.22)$ & $2.38(0.13)$ & $0.51(0.13)$ \\
\hline \multirow[t]{2}{*}{ Lieu 1999} & $\mathrm{~A}$ & $\mathrm{ED} / \mathrm{HOS}$ & $-1.05(0.31)$ & $1.41(0.55)$ & $1.05(0.23)$ & $1.96(0.32)$ & $0.15(0.16)$ & $0.39(0.27)$ & $2.22(0.12)$ & $0.64(0.21)$ \\
\hline & B & ED/HOS & $-3.61(0.30)$ & $0.02(0.52)$ & $-1.52(0.12)$ & $-0.74(0.15)$ & $0.09(0.16)$ & $0.15(0.28)$ & $2.16(0.12)$ & $0.40(0.21)$ \\
\hline Ellman 1997 & & OCS & $-1.48(0.21)$ & $0.48(0.22)$ & $-0.15(0.13)$ & $0.63(0.14)$ & $-1.79(0.19)$ & $0.04(0.17)$ & $0.83(0.13)$ & $0.30(0.11)$ \\
\hline \multicolumn{11}{|c|}{$\begin{array}{l}\text { * ED, emergency department-visit; HOS, hospitalisation; OCS, systemic corticosteroids; UV, unplanned visit. Standard outcome is defined as American } \\
\text { Thoracic Society/European Respiratory Society defined severe exacerbation: systemic corticosteroids for at least } 3 \text { days, ED visit and/or hospitalisation } \\
\text { requiring systemic corticosteroids. [15] } \\
\text { CIL, calibration-in-the-large (difference between the mean predicted and mean observed risk). This measure indicates whether predictions are } \\
\text { systematically too high or low; the closer to } 0 \text {, the better the calibration. The calibration slope (or regression coefficient: the increase in risk when any } \\
\text { predictor increases by one unit) reflects the strength of the predictors; the closer to } 1 \text {, the better the calibration. SE, standard error } \\
\text { Models merely reporting scores could not be assessed for calibration. }\end{array}$} \\
\hline
\end{tabular}




\section{Figure E2 Comparisons of calibration plots}

Exacerbation Primary care Secondary care

definition

\section{Eisner_ocs}

ATS/ERS

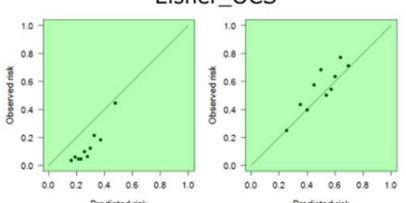

Author

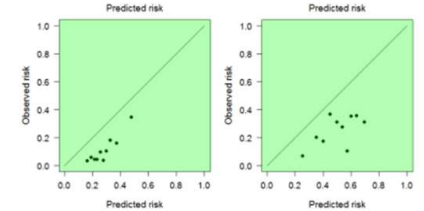

Sato

ATS/ERS

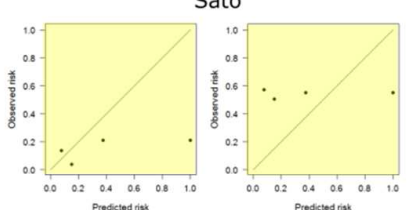

Author

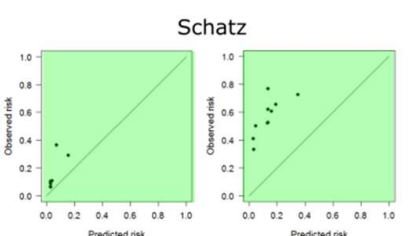

Author

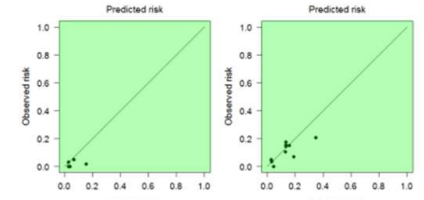

Primary care Secondary care
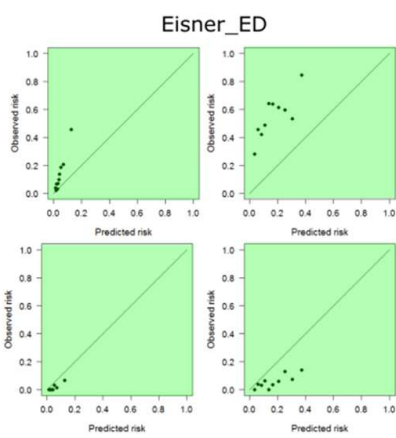

Miller
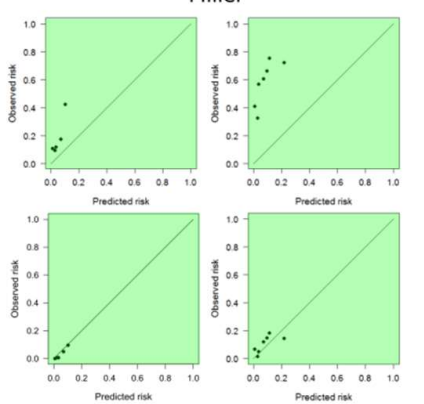

Lieu_A
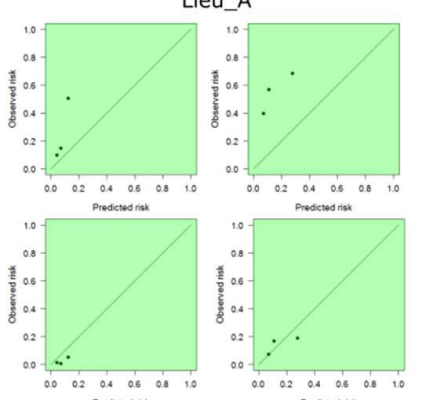

Primary care Secondary care

Eisner_HOS
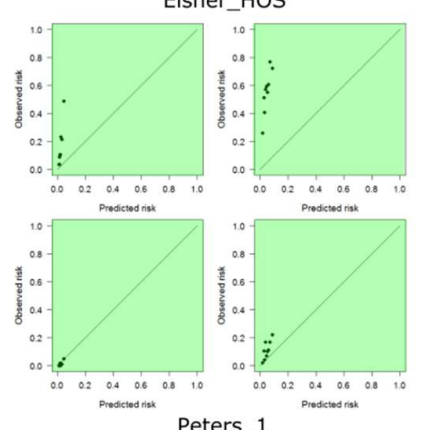

Peters
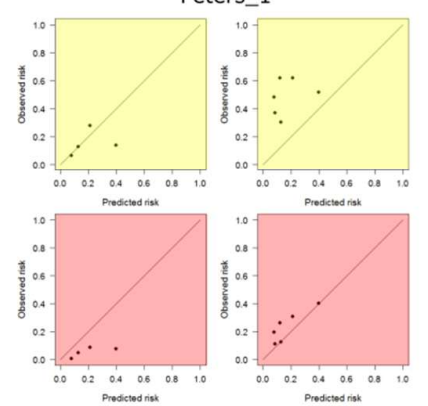

Lieu_B
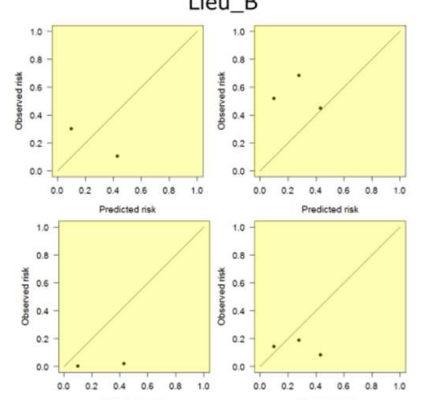

Primary care Secondary care
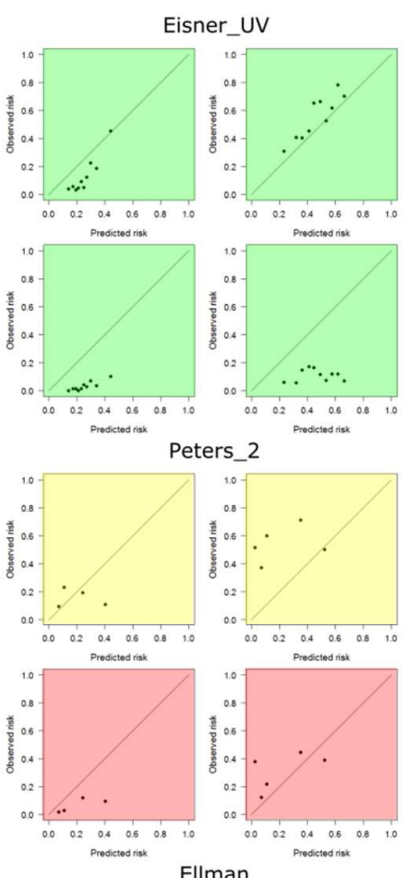

Ellman
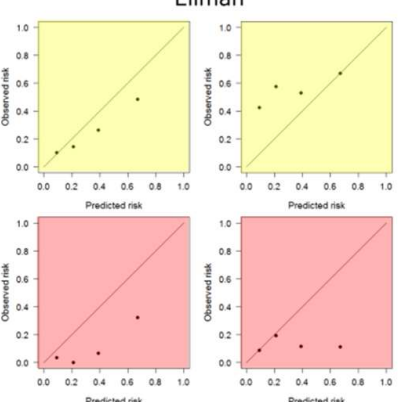

Figure E2: comparisons of calibration plots in the primary (Accurate) and secondary (U-BIOPRED) care cohorts

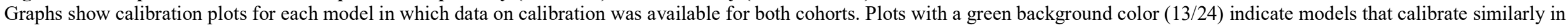

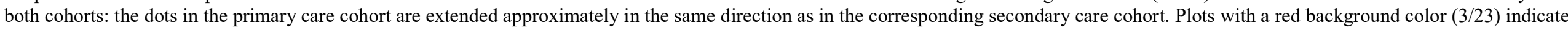

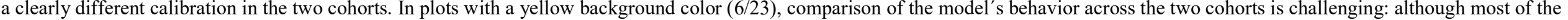

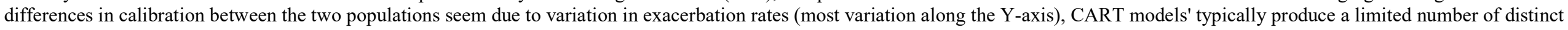
risk estimates. 


\section{APPENDIX U-BIOPRED study group}

The members of the U-BIOPRED Study Group are as follows:

Adcock Ian, National Heart and Lung Institute, Imperial College, London, UK; Adriaens Nora, Academic Medical Centre, University of Amsterdam, Amsterdam, The Netherlands; Ahmed Hassan, European Institute for Systems Biology and Medicine, CNRS-ENS-UCBL-INSERM, Lyon, France; Aliprantis Antonios, Merck Research Laboratories, Boston, USA; Alving Kjell, Dept Women's \& Children's Health, Uppsala University, Uppsala, Sweden; Auffray Charles, European Institute for Systems Biology and Medicine, CNRS-ENS-UCBLINSERM, Lyon, France; Badorrek Philipp, Fraunhofer ITEM; Hannover, Germany Bakke Per, Department of Clinical Science, University of Bergen, Bergen, Norway; Balgoma David, Centre for Allergy Research, Karolinska Institutet, Stockholm, Sweden;Bansal Aruna T., Acclarogen Ltd, St. John's Innovation Centre, Cambridge, UK; Barber Clair, NIHR Southampton Respiratory Biomedical Research Unit and Clinical and Experimental Sciences, Southampton, UK; Baribaud Frédéric, Janssen R\&D, USA; Bates Stewart, Respiratory Therapeutic Unit, GSK, London, UK; Bautmans An, MSD, Brussels, Belgium; Behndig Annelie F., Dept of Public Health and Clinical Medicine, Umeå University, Umeå, Sweden; Bel Elisabeth, Academic Medical Centre, University of Amsterdam, Amsterdam, The Netherlands; Beleta Jorge, Almirall S.A., Barcelona, Spain; Berglind Ann, Dept. Women's and Children's Health \& Centre for Allergy Research, Karolinska Institutet, Stockholm, Sweden; Berton Alix, AstraZeneca, Mölndal, Sweden; Bigler Jeannette, Previously at: Amgen Inc.; Bisgaard Hans, COPSAC, Copenhagen Prospective Studies on Asthma in Childhood, Herlev and Gentofte Hospital, University of Copenhagen, Copenhagen, Denmark; Bochenek Grazyna, II Department of Internal Medicine, Jagiellonian University Medical College, Krakow, Poland; Boedigheimer Michel J., Amgen Inc.; Thousand Oaks, USA; Bøonnelykke Klaus, COPSAC, Copenhagen Prospective Studies on Asthma in Childhood, Herlev and Gentofte Hospital, University of Copenhagen, Copenhagen, Denmark; Brandsma Joost, University of Southampton, Southampton, UK; Braun Armin, Fraunhofer Institute for Toxicology and Experimental Medicine, Hannover, Germany; Brinkman Paul, Academic Medical Centre, University of Amsterdam, Amsterdam, The Netherlands; Burg Dominic, Centre for Proteomic Research, Institute for Life Sciences, University of Southampton, Southampton, UK; Campagna Davide, Department of Clinical and Experimental Medicine, University of Catania, Catania, Italy; Carayannopoulos Leon, Previously at: MSD, USA; Caruso Massimo, Dept. Clinical and Experimental Medicine, University of Catania, Catania, Italy; Carvalho da Purificação Rocha João Pedro, Royal Brompton and Harefield NHS Foundation Trust, London, UK; Chaiboonchoe Amphun, European Institute for Systems Biology and Medicine, CNRS-ENS-UCBL-INSERM, Lyon, France; Chaleckis Romanas, Centre of Allergy Research, Karolinska Institutet, Stockholm, Sweden; Chanez Pascal, Assistance publique des Hôpitaux de Marseille - Clinique des bronches, allergies et sommeil, Aix Marseille Université, Marseille, France; Chung Kian F., National Heart and Lung Institute, Imperial College, London, UK; Coleman Courtney, Asthma UK, London, UK; Compton Chris, Respiratory Therapeutic Unit, GSK, London, UK; Corfield Julie, Areteva R\&D, Nottingham, UK; D’Amico Arnaldo, University of Rome 'Tor Vergata', Rome Italy; Dahlen Barbro, Karolinska University Hospital \& Centre for Allergy Research, Karolinska Institutet, Stockholm, Sweden; Dahlén Sven-Erik, Centre for Allergy Research, Karolinska Institutet, Stockholm, Sweden; De Alba Jorge, Almirall S.A., Barcelona, Spain; de Boer Pim, HuMedSci, Rotterdam, The Netherlands; De Lepeleire Inge, MSD, Brussels, BE; De Meulder Bertrand, European Institute for Systems Biology and Medicine, CNRS-ENS-UCBL-INSERM, Lyon, France; Dekker Tamara, Academic Medical Centre, University of Amsterdam, Amsterdam, The Netherlands; Delin Ingrid, Centre for Allergy Research, Karolinska Institutet, Stockholm, Sweden; Dennison Patrick, NIHR Southampton Respiratory Biomedical Research Unit, Clinical and Experimental Sciences, NIHR-Wellcome Trust Clinical Research Facility, Faculty of Medicine, University of Southampton, Southampton, UK; Dijkhuis Annemiek, Academic Medical Centre, University of Amsterdam, Amsterdam, The Netherlands; Djukanovic Ratko, NIHR Southampton Respiratory Biomedical Research Unit and Clinical and Experimental Sciences, Southampton, UK; Draper Aleksandra, BioSci Consulting, Maasmechelen, Belgium; Edwards Jessica, Asthma UK, London, UK; Emma Rosalia, Department of Clinical and Experimental Medicine, University of Catania, Catania, Italy; Ericsson Magnus, Karolinska University Hospital, Stockholm, Sweden; Erpenbeck Veit, Translational Medicine, Respiratory Profiling, Novartis Institutes for Biomedical Research, Basel, Switzerland; Erzen Damijan, Boehringer Ingelheim Pharma GmbH \& Co. KG; Biberach, Germany; Faulenbach Cornelia, Fraunhofer ITEM; Hannover, Germany Fichtner Klaus, Boehringer Ingelheim Pharma GmbH \& Co. KG; Biberach, Germany; Fitch Neil, BioSci Consulting, Maasmechelen, Belgium; Fleming Louise J., National Heart and Lung Institute, Imperial College, London, UK; Flood Breda, European Federation of Allergy and Airways Diseases Patient's Associations, Brussels, Belgium; Fowler Stephen J., Centre for Respiratory Medicine and Allergy, Institute of Inflammation and Repair, University of Manchester and University Hospital of South Manchester, Manchester Academic Health Sciences Centre, Manchester, United Kingdom; Frey Urs, University Children's Hospital, Basel, Switzerland; Gahlemann Martina, Boehringer Ingelheim (Schweiz) GmbH,Basel, Switzerland; Galffy Gabriella, Semmelweis University, Budapest, Hungary; Gallart Hector, Centre for Allergy Research, Karolinska 
Institutet, Stockholm, Sweden; Garrett Trevor, BioSci Consulting, Maasmechelen, Belgium; Geiser Thomas, Department of Respiratory Medicine, University Hospital Bern, Switzerland; Gent Julaiha, Royal Brompton and Harefield NHS Foundation Trust, London, UK; Gerhardsson de Verdier Maria, AstraZeneca; Mölndal, Sweden; Gibeon David, National Heart and Lung Institute, Imperial College, London, UK; Gomez Cristina, Centre for Allergy Research, Karolinska Institutet, Stockholm, Sweden; Gove Kerry, NIHR Southampton Respiratory Biomedical Research Unit and Clinical and Experimental Sciences, Southampton, UK; Gozzard Neil, UCB, Slough, UK; Guillmant-Farry Emily, Royal Brompton Hospital, London, UK; Guo Yi-ke, Data Science Institute, Imperial College, London, UK; Hashimoto Simone, Academic Medical Centre, University of Amsterdam, Amsterdam, The Netherlands; Haughney John, International Primary Care Respiratory Group, Aberdeen, Scotland; Hedlin Gunilla, Dept. Women's and Children's Health \& Centre for Allergy Research, Karolinska Institutet, Stockholm, Sweden; Hekking Pieter-Paul, Academic Medical Centre, University of Amsterdam, Amsterdam, The Netherlands; Henriksson Elisabeth, Karolinska University Hospital \& Karolinska Institutet, Stockholm, Sweden; Hewitt Lorraine, NIHR Southampton Respiratory Biomedical Research Unit, Southampton, UK; Higgenbottam Tim, Allergy Therapeutics, West Sussex, UK; Hoda Uruj, Imperial College, London, UK; Hohlfeld Jens, Fraunhofer Institute for Toxicology and Experimental Medicine, Hannover, Germany; Holweg Cecile, Respiratory and Allergy Diseases, Genentech, San Francisco, USA; Horvath Ildiko, Semmelweis University, Budapest, Hungary; Howarth Peter, NIHR Southampton Respiratory Biomedical Research Unit, Clinical and Experimental Sciences and Human Development and Health, Southampton, UK; Hu Richard, Amgen Inc. Thousand Oaks, USA; Hu Sile, National Heart and Lung Institute, Imperial College, London, UK; Hu Xugang, Amgen Inc.; Thousand Oaks, USA; Hudson Val, Asthma UK, London, UK; James Anna J., Centre for Allergy Research, Karolinska Institutet, Stockholm, Sweden; Johnson Katy, Centre for respiratory medicine and allergy, Institute of Inflammation and repair, University Hospital of South Manchester, NHS Foundation Trust, Manchester, UK; Kamphuis Juliette, Longfonds, Amersfoort, The Netherlands; Kennington Erika J., Asthma UK, London, UK; Kerry Dyson, romSource, Stirling, UK; Kerry Gina, Centre for respiratory medicine and allergy, Institute of Inflammation and repair, University Hospital of South Manchester, NHS Foundation Trust, Manchester, UK; Klüglich Matthias, Boehringer Ingelheim Pharma GmbH \& Co. KG; Biberach, Germany; Knobel Hugo, Philips Research Laboratories, Eindhoven, The Netherlands; Knowles Richard, Arachos Pharma, Stevenge, UK; Knox Alan, Respiratory Research Unit, University of Nottingham, Nottingham, UK; Kolmert Johan, Centre for Allergy Research, Karolinska Institutet, Stockholm, Sweden; Konradsen Jon, Dept. Women's and Children's Health \& Centre for Allergy Research, Karolinska Institutet, Stockholm, Sweden; Kots Maxim, Chiesi Pharmaceuticals, SPA, Parma, Italy; Krueger Linn, University Children's Hospital Bern, Switzerland; Krug Norbert, Fraunhofer Institute for Toxicology and Experimental Medicine, Hannover, Germany; Kuo Scott, National Heart and Lung Institute, Imperial College, London, UK; Kupczyk Maciej, Centre for Allergy Research, Karolinska Institutet, Stockholm, Sweden Lambrecht Bart, University of Gent, Gent, Belgium; Lantz Ann-Sofie, Karolinska University Hospital \& Centre for Allergy Research, Karolinska Institutet, Stockholm, Sweden; Larsson Lars, AstraZeneca, Mölndal, Sweden; Lazarinis Nikos, Karolinska University Hospital \& Karolinska Institutet, Stockholm, Sweden; Lefaudeux Diane, European Institute for Systems Biology and Medicine, CNRS-ENS-UCBL-INSERM, Lyon, France; Lone-Latif Saeeda, Academic Medical Centre, University of Amsterdam, Amsterdam, The Netherlands; Lowe Lesley, Centre for respiratory medicine and allergy, Institute of Inflammation and repair, University Hospital of South Manchester, NHS Foundation Trust, Manchester, UK; Loza Matthew J., Janssen R\&D, USA; Lutter Rene, Academic Medical Centre, University of Amsterdam, Amsterdam, The Netherlands; Marouzet Lisa, NIHR Southampton Respiratory Biomedical Research Unit, Southampton, UK; Martin Jane, NIHR Southampton Respiratory Biomedical Research Unit, Southampton, UK; Masefield Sarah, European Lung Foundation, Sheffield, UK; Mathon Caroline, Centre of Allergy Research, Karolinska Institutet, Stockholm, Sweden; Matthews John G., Respiratory and Allergy Diseases, Genentech, San Francisco, USA; Mazein Alexander, European Institute for Systems Biology and Medicine, CNRS-ENS-UCBL-INSERM, Lyon, France; Meah Sally, National Heart and Lung Institute, Imperial College, London, UK; Meiser Andrea, National Heart and Lung Institute, Imperial College, London, UK; Menzies-Gow Andrew, Royal Brompton and Harefield NHS Foundation Trust, London, UK; Metcalf Leanne, Previously at: Asthma UK, London, UK; Middelveld Roelinde, Centre for Allergy Research, Karolinska Institutet, Stockholm, Sweden; Mikus Maria, Science for Life Laboratory \& The Royal Institute of Technology, Stockholm, Sweden; Miralpeix Montse, Almirall, Barcelona, Spain; Monk Philip, Synairgen Research Ltd, Southampton, UK; Montuschi Paolo, Università Cattolica del Sacro Cuore, Milan, Italy; Mores Nadia, Università Cattolica del Sacro Cuore, Milan, Italy; Murray Clare S., Centre for Respiratory Medicine and Allergy, Institute of Inflammation and Repair, University of Manchester and University Hospital of South Manchester, Manchester Academic Health Sciences Centre, Manchester, United Kingdom; Musial Jacek, Department of Internal Medicine, Jagiellonian University Medical College, Krakow, Poland; Myles David, Respiratory Therapeutic Unit, GSK, London, UK; Naz Shama, Centre for Allergy Research, Karolinska Institutet, Stockholm, Sweden; Nething Katja, Boehringer Ingelheim Pharma GmbH \& Co. KG; Biberach, Germany; Nicholas Ben, University of Southampton, Southampton, UK; Nihlen Ulf, AstraZeneca; Mölndal, 
Sweden; Nilsson Peter, Science for Life Laboratory \& The Royal Institute of Technology, Stockholm, Sweden; Nordlund Björn, Dept. Women's and Children's Health \& Centre for Allergy Research, Karolinska Institutet, Stockholm, Sweden; Nsubuga Sheila, Royal Brompton Hospital, London, UK; Östling Jörgen, AstraZeneca, Mölndal, Sweden; Pacino Antonio, Lega Italiano Anti Fumo, Catania, Italy; Pahus Laurie, Assistance publique des Hôpitaux de Marseille, Clinique des bronches, allergies et sommeil Espace Éthique Méditerranéen, AixMarseille Université, Marseille, France; Palkonen Susanna, European Federation of Allergy and Airways Diseases Patient's Associations, Brussels, Belgium; Pandis Ioannis, Data Science Institute, Imperial College, London, UK; Pavlidis Stelios, National Heart and Lung Institute, Imperial College, London, UK; Pennazza Giorgio, University of Rome 'Tor Vergata', Rome Italy; Petrén Anne, Centre for Allergy Research, Karolinska Institutet, Stockholm, Sweden; Pink Sandy, NIHR Southampton Respiratory Biomedical Research Unit, Southampton, UK; Postle Anthony, University of Southampton, UK; Powel Pippa, European Lung Foundation, Sheffield, UK; Rahman-Amin Malayka, Previously at: Asthma UK, London, UK; Rao Navin, Janssen R\&D, USA; Ravanetti Lara, Academic Medical Centre, University of Amsterdam, Amsterdam, The Netherlands; Ray Emma, NIHR Southampton Respiratory Biomedical Research Unit, Southampton, UK; Reinke Stacey, Centre for Allergy Research, Karolinska Institutet, Stockholm, Sweden; Reynolds Leanne, Previously at: Asthma UK, London, UK; Riemann Kathrin, Boehringer Ingelheim Pharma GmbH \& Co. KG; Biberach, Germany; Riley John, Respiratory Therapeutic Unit, GSK, London, UK; Robberechts Martine, MSD, Brussels, Belgium; Roberts Amanda, Asthma UK, London, UK; Roberts Graham, NIHR Southampton Respiratory Biomedical Research Unit, Clinical and Experimental Sciences and Human Development and Health, Southampton, UK; Rossios Christos, National Heart and Lung Institute, Imperial College, London, UK; Rowe Anthony, Janssen R\&D, UK; Russell Kirsty, National Heart and Lung Institute, Imperial College, London, UK; Rutgers Michael, Longfonds, Amersfoort, The Netherlands; Sandström Thomas, Dept of Public Health and Clinical Medicine, Umeå University, Umeå, Sweden; Santini Giuseppe, Università Cattolica del Sacro Cuore, Milan, Italy; Santoninco Marco, University of Rome 'Tor Vergata', Rome Italy; Saqi Mansoor, European Institute for Systems Biology and Medicine, CNRS-ENS-UCBL-INSERM, Lyon, France; Schoelch Corinna, Boehringer Ingelheim Pharma GmbH \& Co. KG, Biberach, Germany; Schofield James P. R., Centre for Proteomic Research, Institute for Life Sciences, University of Southampton, Southampton, UK; Seibold Wolfgang, Boehringer Ingelheim Pharma $\mathrm{GmbH}$, Biberach, Germany; Shaw Dominick E., Respiratory Research Unit, University of Nottingham, UK; Sigmund Ralf, Boehringer Ingelheim Pharma GmbH \& Co. KG; Biberach, Germany Singer Florian, University Children's Hospital, Zurich, Switzerland; Sjödin Marcus, Centre for Allergy Research, Karolinska Institutet, Stockholm, Sweden; Skipp Paul J., Centre for Proteomic Research, Institute for Life Sciences, University of Southampton, Southampton, UK; Smids Barbara, Academic Medical Centre, University of Amsterdam, Amsterdam, The Netherlands; Smith Caroline, NIHR Southampton Respiratory Biomedical Research Unit, Southampton, UK; Smith Jessica, Asthma UK, London, UK; Smith Katherine M., University of Nottingham, UK; Söderman Päivi, Dept. Women's and Children's Health, Karolinska Institutet, Stockholm, Sweden; Sogbesan Adesimbo, Royal Brompton and Harefield NHS Foundation Trust, London, UK; Sousa Ana R., Respiratory Therapeutic Unit, GSK, London, UK; Staykova Doroteya, University of Southampton, Southampton, UK; Stephan Simon, Centre for respiratory medicine and allergy, Institute of Inflammation and repair, University Hospital of South Manchester, NHS Foundation Trust, Manchester, UK; Sterk Peter J., Academic Medical Centre, University of Amsterdam, Amsterdam, The Netherlands; Strandberg Karin, Karolinska University Hospital \& Karolinska Institutet, Stockholm, Sweden; Sun Kai, National Heart and Lung Institute, Imperial College, London, UK; Sunthar Meera, Centre for respiratory medicine and allergy, Institute of Inflammation and repair, University Hospital of South Manchester, NHS Foundation Trust, Manchester, UK; Supple David, Asthma UK, London, UK; Szentkereszty Marton, Semmelweis University, Budapest, Hungary; Tamasi Lilla, Semmelweis University, Budapest, Hungary; Tariq Kamran, NIHR Southampton Respiratory Biomedical Research Unit, Clinical and Experimental Sciences, NIHR-Wellcome Trust Clinical Research Facility, Faculty of Medicine, University of Southampton, Southampton, UK; Thörngren John-Olof, Karolinska University Hospital, Stockholm, Sweden; Thornton Bob, MSD, USA; Thorsen Jonathan, COPSAC, Copenhagen Prospective Studies on Asthma in Childhood, Herlev and Gentofte; Hospital, University of Copenhagen, Copenhagen, Denmark; Valente Salvatore, Università Cattolica del Sacro Cuore, Milan, Italy; van Aalderen Wim, Academic Medical Centre, University of Amsterdam, Amsterdam, The Netherlands; van de Pol Marianne, Academic Medical Centre, University of Amsterdam, Amsterdam ,The Netherlands; van Drunen Kees, Academic Medical Centre, University of Amsterdam, Amsterdam, The Netherlands; van Geest Marleen, AstraZeneca, Mölndal, Sweden; Versnel Jenny, Previously at: Asthma UK, London, UK; Vestbo Jorgen, Centre for Respiratory Medicine and Allergy, Institute of Inflammation and Repair, University of Manchester and University Hospital of South Manchester, Manchester Academic Health Sciences Centre, Manchester, United Kingdom; Vink Anton, Philips Research Laboratories, Eindhoven, The Netherlands; Vissing Nadja, COPSAC, Copenhagen Prospective Studies on Asthma in Childhood, Herlev and Gentofte Hospital, University of Copenhagen, Copenhagen, Denmark; von Garnier Christophe, University Hospital Bern, Switzerland; Wagener Ariane, Academic Medical Centre, University of Amsterdam, Amsterdam, The Netherlands; Wagers Scott, 
BioSci Consulting, Maasmechelen, Belgium; Wald Frans, Boehringer Ingelheim Pharma GmbH \& Co. KG, Biberach, Germany; Walker Samantha, Asthma UK, London, UK; Ward Jonathan, Histochemistry Research Unit, Faculty of Medicine, University of Southampton, Southampton, UK; Weiszhart Zsoka, Semmelweis University, Budapest, Hungary; Wetzel Kristiane, Boehringer Ingelheim Pharma GmbH, Biberach, Germany; Wheelock Craig E., Centre for Allergy Research, Karolinska Institutet, Stockholm, Sweden; Wiegman Coen, National Heart and Lung Institute, Imperial College, London, UK; Williams Siân, International Primary Care Respiratory Group, Aberdeen, Scotland; Wilson Susan J., Histochemistry Research Unit, Faculty of Medicine, University of Southampton, Southampton, UK; Woodcock Ashley, Centre for Respiratory Medicine and Allergy, Institute of Inflammation and Repair, University of Manchester and University Hospital of South Manchester, Manchester Academic Health Sciences Centre, Manchester, United Kingdom; Yang Xian, National Heart and Lung Institute, Imperial College, London, UK; Yeyasingham Elizabeth, UK Clinical Operations, GSK, Stockley Park, UK; Yu Wen, Amgen Inc.; Thousand Oaks, USA; Zetterquist Wilhelm, Dept. Women's and Children's Health \& Centre for Allergy Research, Karolinska Institutet, Stockholm, Sweden; Zwinderman Koos, Academic Medical Centre, University of Amsterdam, The Netherlands. 